\title{
İmam Hatip Liselerindeki Suriyeli Öğrencilerin Din Eğitimi Sorunları: Çözüme Yönelik Nitel Bir Analiz
}

\author{
ALİ BALTACI \\ Muş Alparslan Üniversitesi İslami İlimler Fakültesi \\ a.baltaci@alparslan.edu.tr \\ https://orcid.org/0000-0003-2550-8698 \\ MEHMET KAMIL COȘKUN \\ Ankara Hacı Bayram Veli Üniversitesi İlahiyat Fakültesi \\ kamil.coskun@hbv.edu.tr \\ (D) https://orcid.org/0000-0002-5669-2777 \\ ISA CEYLAN \\ Ankara Üniversitesi İlahiyat Fakültesi \\ isa.ceylan@ankara.edu.tr \\ https://orcid.org/0000-0002-6163-5689
}

\begin{abstract}
Öz
$\mathrm{Bu}$ araştırma, imam hatip liselerinde çalışan din dersi öğretmenlerinin görüşleri doğrultusunda, bu okullarda öğrenim gören Suriyeli öğrencilerin din eğitimi derslerinde yaşadıkları sorunlara odaklanmaktadır. Ayrıca araştırma kapsamında din dersi öğretmenlerinin, din derslerinde yaşanan sorunlara ilişkin çözüm önerileri de sunulmaktadır. Nitel araştırma yöntemlerinden fenomenolojik desende tasarlanan bu araştırmada ölçüt ve kartopu örnekleme yöntemleri eş zamanlı olarak işe koşularak karma örnekleme yaklaşımı kullanılmıştır. Ankara İlinin Altındağ, Mamak, Sincan, Çankaya, Yenimahalle ve Etimesgut ilçelerinde bulunan 17 imam hatip lisesinde çalışan 43 din dersi öğretmeni bu araştırmanın çalışma grubudur. Araştırma sonuçlarına göre; dilde, iletişimde, okul içinde ve okul dışında yaşanan sorunların yanı sıra sosyal dışlanma ve önyargılar temaları altında belirlenen sorunlar söz konusudur. Öğretmenler için en önemli sorun kaynakları: Suriyeli öğrencilerin Türkçe bilmemesi ve diğerleriyle iletişim kuramamasıdır. Bu sorunların çözümü için öğretmenler, dil eğitimi, empati eğitimi ve uyum eğitimi ile Suriyelilere özel okulların açılmasına yönelik çeşitli öneriler sunmuşlardır. Din eğitimi literatüründe ilgili soruna odaklanan bir çalışma olması ve ileride yapılacak çalışmalar için önemli veri kaynağı oluşturması araştırmanın önemini artırmaktadır.
\end{abstract}

Anahtar Kelimeler: Din Eğitimi, Din Dersi Öğretmenleri, İmam Hatip Liseleri, Suriyeli Öğrenciler. 


\section{The Religious Education Problems of Syrian Students in Religious-Based (Imam Hatip) High Schools: A Qualitative Analysis for Solution \\ Abstract}

This research focuses on the problems experienced by the Syrian students studying in the religious-based (imam hatip) high schools in the religious education courses in accordance with the opinions of the religious education teachers. Within the scope of the research, some solutions offered by religious education teachers regarding the problems encountered in classes are presented. In this study, which is designed with a phenomenological model, one of the qualitative research methods, criterion and snowball sampling methods are employed simultaneously and mixed sampling approach is used. The study group consists of 43 religious teachers working in 17 imam hatip high schools in Altındağ, Mamak, Sincan, Çankaya, Yenimahalle, and Etimesgut districts of Ankara. According to the results of the research, there are problems identified under these themes: language and communication problems inside and outside the school, social exclusion, and prejudice. According to teachers, the most important causes of the problems are that Syrian students do not speak Turkish and cannot communicate with others. In order to solve these problems, teachers have offered various suggestions, including providing language education, empathy training and adaptation education, and opening private schools for Syrians. The fact that this study focuses on the related problem in the literature of religious education and constitutes an important data source for future studies increases the importance of the research.

Keywords: Religious Education, Religious Education Teachers, Imam Hatip High Schools, Syrian Students.

\section{Giriş}

Tarihsel olarak süregelen bir gerçeklik olan göç kavramı, insanlığın karşılaştığı önemli varoluşsal sorunlardan biridir. İnsanların yaşadığı coğrafyalardan iklim, kıtlık, savaşlar veya diğer siyasal, sosyal, kültürel ve ekonomik olaylar nedeniyle yer değiştirmesi ${ }^{1}$ olarak tanımlanan göç, bir ülke sınırları içinde veya sınırları aşarak uluslararası bir niteliğe sahip olabilir. Bireysel ve kitleler halinde de görülebilen göçler, çoğu durumda göç eden kişi veya kitlelerin yaşantısında kalıcı izler bırakmakta ve onların göç ettikleri yerlerde çeşitli sorunlar yaşamalarına neden olabilmektedir. ${ }^{2}$ Özellikle kitlesel göç hareketleri, savaş veya iklim değişiklikleri gibi toplum yaşantısını derinden etkileyen olayların sonucudur. Kitlesel göçlerin, zorunlu göç kapsamında değerlendirilmesi için (1) ülke nüfusunun en az \%1'lik bölümünün yaşamının tehdit altında olması ve (2) en az yüz bin kişinin yaşadığı toprak-

\footnotetext{
${ }^{1}$ Filippo Simini ve diğerleri, "A Universal Model for Mobility and Migration Patterns," Nature 484 (2012), s.96.

2 Dorrit Posel, "Have Migration Patterns in Post-Apartheid South Africa Changed?," Journal of Interdisciplinary Economics 15:3-4 (2004), s.277.
} 
ları terk etmek zorunda olması gerekmektedir. ${ }^{3}$ Günümüzde Suriye, Irak ve Afganistan'dan Türkiye'ye doğru artan oranda devam eden göç hareketi, zorunlu, kitlesel ve dış göç kapsamında ele alınabilir.

Özellikle son dönemlerde Türkiye'ye doğru yönelen dış göç, toplum içinde farklı alanlarda çeşitli huzursuzluklar yaratmakta, sosyal uyumu zorlayıcı ayrışmalara neden olabilmektedir. Şehirlerin demografik yapısını değiştiren ve sosyal alanlarda gerilimlere neden olan göçmenler, eğitim sistemini de etkilemektedir. ${ }^{4}$ Eğitim sisteminin en önemli girdisi olan öğrenci kalitesi, okullarda verilen eğitim-öğretim hizmetlerinin etkinliğini de arttırır. Suriyeli öğrencilerin öğrenim gördüğü okullarda yaşanan çeşitli sorunlar, farklı yollarla çözülmesine rağmen, politika belirleyicilerin bu önemli olguya henüz toplum tarafından kabul görmüş bir çözüm getirmediği söylenebilir. Bu alanda oluşmaya başlayan akademik literatüre rağmen, Suriyeli göçmen öğrencilerin din eğitimine etkileri konusunda sınırlı sayıda araştırma bulunmaktadır. Bu çalışma, genel olarak alandaki sınırlı literatüre anlamlı katkı sunmayı özel olarak ise Suriyeli öğrencilerin eğitim gördüğü okullarda çalışan din dersi öğretmenlerinin karşılaştığı sorunları belirlemeyi amaçlamaktadır. Ayrıca araştırma ile soruna yönelik farklı çözüm önerilerinin geliştirilmesi de hedeflenmektedir.

\section{Göç ve Eğitim Olgusu}

Göç hareketleri, gerek göç eden gruplar ve göçe maruz kalan ülkelerdeki toplumsal düzeni, gerekse birey ve toplumları farklı şekillerde etkileyen bir olgudur. Göç edenlerin yeni yerleştikleri topluma uymaları ve göç alan toplulukların da göç edenleri kabul etme süreci, politik, toplumsal, ekonomik ve kültürel zorluklara neden olabilmektedir. Söz konusu zorluklar, farklı kültürlerin karıştığı uluslararası göçlerde daha belirginleşir. Göç, kişilerarası iletişim sorunları, ölümler, çatışmalar veya kayıplar gibi bireyin yaşamında önemli psiko-sosyal dönüşümlere neden olabilen travmatik deneyimleri de barındırır. ${ }^{5}$

Türkiye'de 1960'lar boyunca artan iç göçlere ek olarak 1970'lerde dış göçler başlamış, özellikle 2010'lu yıllardan itibaren Ortadoğu ve diğer böl-

\footnotetext{
${ }^{3}$ Virginie Guiraudon, "European Integration and Migration Policy: Vertical Policy-Making as Venue Shopping," JCMS: Journal of Common Market Studies 38:2 (2000), s.263.

4 Zeynep Aksoy, "Uluslararası Göç ve Kültürlerarası İletişim," Uluslararası Sosyal Araştırmalar Dergisi 5:20 (2012), s.294.

${ }^{5}$ Betül Dilara Şeker ve diğerleri, Göç ve Uyum (Londra: Transnational Press, 2015), ss.63-64; Everett S. Lee, "A Theory of Migration," Demography 3:1 (1966), ss.47-57; Nikos Papastergiadis, The Turbulence of Migration: Globalization, Deterritorialization and Hybridity (New York: John Wiley \& Sons, 2018), s.53.
} 
gelerdeki savaşların da etkisiyle ülkemize yönelen dış göç hızlanmıştır. Son yıllarda farklı dinî ve etnik kökenlere sahip olan göç akınlarına maruz kalan Türkiye, transit göçmen, mülteci, sığınmacı, kaçak işçi veya diğer yollarla ülkeye giren önemli bir göçmen kitlesine ev sahipliği yapmaktadır. ${ }^{6}$ Türkiye'ye doğru gerçekleşen göç hareketinin önemli bir bölümü güney komşumuz Suriye kaynaklı göç dalgasıdır. 2011 yılında Suriye'de başlayan iç savaşla birlikte can güvenliklerinin tehdit altında olduğunu düşünen Suriye vatandaşları, Türkiye, Lübnan ve Ürdün gibi ülkelere sığınmışlardır. ${ }^{7}$ Bunlar arasında Türkiye en fazla Suriyeli sığınmacıya ev sahipliği yapan ülke olarak öne çıkmaktadır. Uluslararası Göç Örgütü (IOM) 2019 yılı verilerine göre Türkiye, 3 milyondan fazla (3 milyon 630 bin 767 kişi) kayıtlı Suriyeli mülteciye ev sahipliği yapmaktadır. Ülkedeki Suriyeli mültecilerin büyük çoğunluğu başta İstanbul olmak üzere kentsel alanlarda yaşamakta olup 260.000 'den fazlasına hükümet tarafından yönetilen 26 barınma merkezinde konaklama imkanı sağlanmaktadır. ${ }^{8}$ Türkiye'deki Suriyelilerin hukuki statüsü "mülteci" olarak adlandırılmamakta; 1951 yılında imzalanan "Mültecilerin Hukuki Statüsüne İlişsin Protokol" (Cenevre Sözleşmesi) ve 1967 yılında imzalanan "Birleşmiş Milletler Devlete Sığınmaya İlişkin Beyanname”ye göre Suriyelilerin Türkiye'deki hukuki durumu belirlenmektedir. Söz konusu iki protokolle Türkiye, Avrupa'dan Türkiye'ye göç edenleri mülteci olarak tanımlarken, Avrupa dışından göç edenleri "şartlı mülteci" olarak adlandırmakta; mülteciliğe ilişkin işlemleri ise Birleşmiş Milletler Mülteciler Yüksek Komiserliği ile işbirliği içerisinde yürütmektedir. ${ }^{9}$ Buna karşın Suriyelilerin Türkiye'deki statüsünün ne olacağına dair tartışmalar devam etmiş; Türkiye, 2011 yılı Mart ayında ülke sınırlarından giriş yapmaya başlayan Suriyelilerin hiçbirini geri göndermeme kararı almış ve "Açık Kapı Politikası" uygulamasını hayata geçirerek Suriyelilere "Geçici Koruma Statüsü" vermiştir.10 Geçici koruma, "ülkesinden zorla çıkarılmış, ülkesine dönme ihtimali olmayan, acil ve geçici sığınma bulma maksadıyla bireysel

\footnotetext{
${ }^{6}$ Şeker ve diğerleri, Göç ve Uyum, s.69.

7 Zeki Boyraz, "Türkiye’de Göçmen Sorununa Örnek Suriyeli Mülteciler," Zeitschrift für die Welt der Türken 7:2 (2015), s.36.

8 IOM, “IOM Turkey Report - Migrants' Presence Monitoring 2019," IOM, 2019, https://turkey.iom.int/sites/default/files/Q1_quarterly-jan-feb-mar-19.reduced.pdf (26.04.2019).

9 Dilek Canyurt, "Suriye Gelişmeleri Sonrası Suriyeli Mülteciler: Türkiye'de Riskler," Akademik Bakış 48:1 (2015), s.129.

${ }^{10}$ Bilhan Kartal, “Türkiye’ye Yönelik Suriyeli Göçünün Çok Yönlü Doğasına Giriș,” B. Kartal ve U. Manço (ed.), Beklenmeyen Misafirler: Suriyeli Siğınmacılar Penceresinden Türkiye Toplumunun Geleceği (Londra: Transnational Press, 2018) içinde, ss.13-29.
} 
veya gruplar halinde başka bir ülke sınırlarına gelen veya sınırları izinli/izinsiz geçen yabancılara sağlanan koruma" olarak tanımlanabilir. ${ }^{11}$

Suriye'den gelen ve geçici sığınma kamplarında ikamet edenlerin tüm ihtiyaçları devlet kaynaklarından karşılanmaktayken, kamp dışındaki sığınmacıların ihtiyaçları sınırlı ölçüde karşılanabilmektedir. Suriyelilerin yaklaşık \% 93'ü sığınma kampları dışında yaşadığından, göç olgusunun beraberinde getirdiği sorunların büyük çoğunluğunu kentlerde yaşayanların karşılaştıkları çeşitli sorunlar oluşturmaktadır.12 Kentlerde yaşayan Suriyeli sığınmacıların yaşadığı temel sorun, Türk gelenek ve görenekleri ile kültürel yapısına uyum sağlamaktır. ${ }^{13}$ Ayrıca Suriyeliler, barınma, istihdam, sağlık, eğitim, güvenlik ve sosyal yardım hizmetlerine erișim gibi sorunlarla da karşılaşabilmektedirler. ${ }^{14}$ Suriyeli sığınmacıların önemli sorunlarından birisi olan eğitim, Türkiye'nin taraf olduğu uluslararası yükümlülükler gereği kamu imkanları kapsamında karşılanmaktadır. Sağlanan eğitim imkanlarından mahrum olan çocuklar, gelecekte kamusal alanda farklı sorunlar oluşturabilirler. ${ }^{15}$ Eğitim, çocuğu sosyalleştirerek diğer çocuklarla iletişim kurmasını ve bu dolayımda topluma uymasını kolaylaştırır. Eğitim yoluyla farklı çocuklarla iletişim kuran sığınmacı çocuklar, kendilerini bir grubun ve toplumun parçası olarak değerli hisseder. Gruba aidiyet önemli bir sosyal işlev iken, okul içinde sosyal ilişkilerin kurulmasıyla toplumla olan ilişkilerde de yumuşama görülür. ${ }^{16}$ Okul içinde belirli kuralları öğretmen denetiminde öğrenen sığınmacı çocuklar, toplumu oluşturan daha üst kuralları da burada içselleştirirler. Nitelikli bir eğitim çocukların, bir sömürü aracı olarak kullanılmasını, çeşitli yollarla istismar edilmesini, radikal ideolojilerdeki örgütler tarafından kullanılmalarını engeller. Çocuklarda yeni yeteneklerin gelişmesi, farklı kültürleri tanımaları ve öznel iyi oluşlarının sağlanması gibi olumlu etkileri olan eğitim, çocukların gelecekte edinecekleri mesleklere

\footnotetext{
11 Bilhan Kartal, "Sığınmacı Statüsünün Dönüşümü ve Entegrasyon," B. Kartal ve U. Manço (ed.), Beklenmeyen Misafirler: Suriyeli Siğınmacılar Penceresinden Türkiye Toplumunun Geleceği (Londra: Transnational Press, 2018) içinde, s.119.

12 Doğuş Şimşek, “Göç Politikaları ve 'İnsan Güvenliğii': Türkiye'deki Suriyeliler Örneği," Toplum ve Bilim 147 (2017), s.15.

${ }^{13}$ Işık Tüzün, Türkiye'de Mülteci Çocukların Eğitim Hakkını ve Karşılıklı Uyumu Destekleyen Yaklașımlar, Politikalar ve Uygulamalar (Byy.: European Liberal Forum, 2017), s.12.

${ }^{14}$ Boyraz, "Türkiye'de Göçmen Sorununa Örnek Suriyeli Mülteciler," s.37.

${ }^{15}$ Ali Rıza Seydi, "Türkiye’nin Suriyeli Sığınmacıların Eğitim Sorununun Çözümüne Yönelik İzlediği Politikalar," Süleyman Demirel Üniversitesi Fen-Edebiyat Fakültesi Sosyal Bilimler Dergisi 31 (2014), ss.265-267.

${ }^{16}$ Yusuf Batar, Empatik Din Eğitimi (Ankara: Elips Kitap, 2011), s.22.
} 
yönelik yönlendirme faaliyetlerini de içerir. ${ }^{17}$ Sığınmacı çocuklara sunulan eğitim imkanları hem çocukların hem de ailelerinin toplumla bütünleşmesini kolaylaştıracaktır.

\section{Türk Eğitim Sisteminde Suriyeli Sığınmacı Öğrenciler}

Son dönemde Türkiye'ye yönelik göçün büyük bir kısmını oluşturan Suriyeli sığınmacılar için Milli Eğitim Bakanlığı (MEB) tarafından düzenlenen çeşitli uyum ve eğitim programları bulunmaktadır. Ancak özellikle sınır illerinde yoğunlaşan ve yer yer yerel öğrenci sayısını ikiye katlayan Suriyeli sığınmacılar için oluşturulmuş eğitim politikaları henüz hayata geçirilmemiştir. Tablo 1'de Türkiye'nin bazı illerindeki yerel öğrenci sayıları ile Suriyeli öğrenci sayıları hakkında bilgiler yer almaktadır.

\begin{tabular}{lcccc}
\multicolumn{1}{c}{ Şehir } & $\begin{array}{c}\text { Sığınmacı } \\
\text { Sayısı }\end{array}$ & $\begin{array}{c}\text { İl Nüfusuna } \\
\text { göre } \\
\text { Sı̆̆ınmacı } \\
\text { Oranı (\%) }\end{array}$ & $\begin{array}{c}\text { Sı̆̆ınmacı } \\
\text { Ögrenci Sayısı }\end{array}$ & $\begin{array}{c}\text { İldeki Toplam } \\
\text { Öğrenci Sayısı- } \\
\text { na Göre Sı̆̆ın- } \\
\text { macı Oranı (\%) }\end{array}$ \\
\hline İstanbul & 559428 & 3,69 & 172364 & 3,12 \\
\hline Şanlıurfa & 451201 & 22,06 & 165424 & 45,19 \\
\hline Hatay & 436175 & 27,08 & 146954 & 46,02 \\
\hline Gaziantep & 429654 & 21,14 & 175424 & 43,18 \\
\hline Adana & 238421 & 10,67 & 115024 & 26,78 \\
\hline Mersin & 225648 & 11,26 & 112054 & 27,19 \\
\hline Bursa & 172632 & 5,66 & 83457 & 10,62 \\
\hline İzmir & 145021 & 3,31 & 71026 & 10,24 \\
\hline Kilis & 118021 & 81,65 & 65245 & 93,25 \\
\hline Konya & 110210 & 4,82 & 56248 & 9,72 \\
\hline Mardin & 89124 & 10,69 & 43688 & 22,96 \\
\hline Ankara & 91225 & 1,65 & 56215 & 6,78 \\
\hline Osmaniye & 49652 & 9,14 & 29487 & 22,65 \\
\hline Diyarbakır & 35287 & 1,95 & 19845 & 6,25
\end{tabular}

Tablo 1: 2019 Yllında Çeşitli Şehirlerde Öğrenim Gören Suriyeli Sığınmacı Öğrenci Sayıs 18

\footnotetext{
17 Kudret Aykırı, "Sınıf Öğretmenlerinin Sınıflarındaki Suriyeli Öğrencilerin Eğitim Durumlarına İlișkin Görüșleri," Turkish Journal of Primary Education 2:1 (2017), ss.44-56; Suat Cebeci, Din Eğitimi Bilimi ve Türkiye'de Din Eğitimi (Ankara: Akçağ, 1996), ss.16-17; Recep Kaymakcan ve Hasan Meydan, "Din Kültürü ve Ahlak Bilgisi Programları ve Öğretmenlerine Göre Değerler Eğitimi," Değerler Eğitimi Dergisi 9:21 (2011), ss.30-31; Nurullah Altaş, Gençlik Döneminde Din Olgusu ve Liselerde Din Öğretimi (Ankara: Nobel, 2004), ss.15-18; Beyza Bilgin, Türkiye'de Din Eğitimi ve Liselerde Din Dersleri (Ankara: Emel Matbaacllık, 1980), ss.22-26.
} 
Tablo 1'e göre Kilis'teki öğrencilerin \%93,25'ini, Hatay'daki öğrencilerin \%46,02'sini, Şanlıurfa'daki öğrencilerin \%45,19'unu Suriyeli sığınmacı öğrenciler oluşturmaktadır. Bu durum Türkiye'nin Suriyeli sığınmacıların eğitimi ile ilgili izlediği yaklaşım ve politikaları etkilemiştir. Türkiye'ye giriş yaptıkları 2011 yılından itibaren ülkelerine geri dönecekleri varsayılarak Suriyelilere ilişkin geçici eğitim politikaları üretilmiş; ancak iç savaşın uzun sürmesi ve sığınmacıların geri dönmek istememeleri gibi nedenlerle süreklilik arz eden eğitim politikalarının belirlenmesine öncelik verilmiştir. ${ }^{19}$ Ülke içinde farklı şekillerde ikamet eden Suriyeliler için farklı eğitim imkanları olsa da kamplarda yaşayanların eğitim hizmetlerinden yararlanmaları, şehirlerde yaşayanlara göre daha kolay olmaktadır. Kamplar dışındaki öğrenciler, kamu okullarından dilediklerine kayıt imkanına sahip olmakla birlikte Suriyeliler için özel olarak açılan geçici eğitim merkezleri de bulunmaktadır. Kamu okullarında öğrenim gören Suriyeli sığınmacı öğrenciler, Türk çocuklarına tanınan tüm haklardan yararlanabilmektedir. ${ }^{20}$

Suriye ve Türkiye komşu iki ülke olsa da farklı etnik ve kültürel yapıya sahiptir. Bu farklılık Suriyeli sığınmacıların uyum sorunları yaşamalarına veya Türk vatandaşlarının zaman zaman kamusal alanda yabancılaşma yaşamalarına neden olabilmektedir. ${ }^{21}$ Suriyeli öğrencilerin çoğunluğu dil sorunu yaşadığından ana dillerini kullanarak akranlarıyla ve öğretmenleriyle iletişim kurmaya çalışmakta, bu durum önemli bir iletişim sorununa neden olmaktadır. ${ }^{22} \mathrm{Az}$ sayıda öğrenci savaş ve çatışma bölgelerinden gelse de Suriyeli öğrencilerin büyük çoğunluğunda travma sonrası stres bozuklukları, yabancılara karşı güvensizlik, depresyon gibi negatif psikolojik durumlar söz konusudur. ${ }^{23}$ Akademik olarak başarı beklentisi olmayan Suriyeli veli-

\footnotetext{
18 Verilerin hesaplanmasında Uluslararası Göç Örgütü (IOM), İç İşleri Bakanlığı Göç İdaresi Genel Müdürlüğü ve Milli Eğitim Bakanlığı istatistikleri temel alınmıștır.

${ }^{19}$ Müberra Nur Emin, Türkiye'deki Suriyeli Çocukların Eğitimi: Temel Eğitim Politikaları (Ankara: Seta, 2016), ss.12-14; Canyurt, "Suriye Gelişmeleri Sonrası Suriyeli Mülteciler: Türkiye'de Riskler," s.130; Kartal, "Türkiye’ye Yönelik Suriyeli Göçünün Çok Yönlü Doğasına Giriș," s.15.

20 Derya Kap, "Suriyeli Mülteciler: Türkiye'nin Müstakbel Vatandaşları," Akademik Perspektif 1:3 (2014) ss.30-35; Hilal Barın, "Türkiye'deki Suriyeli Kadınların Toplumsal Bağlamda Yașadıkları Sorunlar ve Çözüm Önerileri," Göç Araștırmaları Dergisi 2 (2015), ss.10-56; Faik Tanrıkulu, "Türkiye'de Yaşayan Suriyeli Çocukların Eğitim Sorunu ve Çözüm Önerileri," Liberal Düşünce Dergisi 22:86 (2017), ss.127-144; Aykırı, "Sınıf Öğretmenlerinin Sınıflarındaki Suriyeli Öğrencilerin Eğitim Durumlarına İlișkin Görüșleri," ss.47-48.

${ }^{21}$ Aksoy, "Uluslararası Göç ve Kültürlerarası İletișim," s.53.

${ }^{22}$ Mehmet Tok ve Musa Yıgın, "Yabancı Uyruklu Öğrencilerin Türkçe Öğrenme Nedenlerine İlişkin Bir Durum Çalışması," Dil ve Edebiyat Eğitimi Dergisi 2:8 (2013), ss.142-143.

${ }^{23}$ Papastergiadis, The Turbulence of Migration, ss.29-30; Ali Ayten ve Zeynep Sağır, "Dindarlık, Dinî Başa Çıkma ve Depresyon İliş̧kisi: Suriyeli Sığınmacılar Üzerine Bir Araştırma," Marmara Üniversitesi İlahiyat Fakültesi Dergisi 47:2 (2014), ss.5-18.
} 
ler, öğrencilerin derslere olan ilgisinin ve akademik öz güvenlerinin azalmasına neden olabilmektedir. ${ }^{24}$ Suriyeli çocukların büyük çoğunluğu okul sırasında veya sonrasında ailelerine destek olmak için farklı işlerde çalışmakta, bu durum okullara devam etmelerini güçleştirdiği kadar okul içinde disiplin sorunları yaşanmasına da neden olabilmektedir. ${ }^{25}$ Okullarda Suriyeli öğrenci sorununa doğrudan maruz kalan öğretmenler, iletişim, disiplin ve davranış sorunu olan sığınmacılarla baş etmede zorlanmaktadırlar. ${ }^{26}$

Geleneksel bir algı olarak din dersi (din kültürü ahlak bilgisi ve imam hatip meslek bilgisi) öğretmenlerinin Arapça bildiği veya temel iletişim sağlayacak kadar bu dili konuştuğu varsayılır. ${ }^{27}$ Dolayısıyla okullarda Suriyeli sığınmacı öğrencilerle yaşanan iletişim sorunlarında, din dersi öğretmenlerinin aracı olarak kullanıldığı; çoğu problemin çözümü için din dersi öğretmenlerinden yardım istendiği bilinmektedir. ${ }^{28}$ Oysaki ilahiyat fakültesi veya din kültürü ve ahlak bilgisi (DKAB) lisans programlarında modern ve klasik Arapça dersleri olsa da bu öğretmenlere günlük yaşam gereksinimleri için pratik Arapça dersleri verilmemektedir. Din dersi öğretmenleri kısıtlı Arapça bilgileri ile Suriyeli sığınmacı öğrencilerle iletişim kurmaya çalışmakta; çoğunlukla yanlış anlaşılmalara dayalı olumsuz iletişim kurabilmektedirler. Hatalı iletişim, mesajın karşıdakine iletilememesi olarak ifade edildiğinden, Suriyeli sığınmacı öğrenci kendini ifade edememekte ve yoğun bir dışlanmışlık ve yalıtılmışlık hissi içine girebilmektedir. ${ }^{29}$

Suriyeli sığınmacıların eğitilmesi gerek okullarda karşılaşılan sorunlar gerekse toplum içindeki gerginliklerin azaltılması noktasında elzemdir.

\footnotetext{
${ }^{24}$ Canyurt, "Suriye Gelișmeleri Sonrası Suriyeli Mülteciler," ss.136-138.

${ }^{25}$ Betül Duman, "Yoğun Göç Almış Metropollerde Etniklik ve Öteki İle İlişki," Sosyoloji Dergisi 3:27 (2013), ss.1-24; Tok ve Yıgın, "Yabancı Uyruklu Öğrencilerin Türkçe Öğrenme Nedenlerine İlişkin Bir Durum Çalışması," s.144.

${ }^{26}$ Cahit Erdem, "Sınıfında Mülteci Öğrenci Bulunan Sınıf Öğretmenlerinin Yaşadıkları Öğretimsel Sorunlar ve Cözüme Dair Önerileri," Medeniyet Eğitim Araștırmaları Dergisi 1:1 (2017), ss.26-42.

${ }^{27}$ Ali Baltacı ve Mehmet Kamil Coşkun, "Din Dersi Öğretmenlerine Yönelik Öğretmen Algısı Ölçeğinin Geliştirilmesi," OPUS Uluslararası Toplum Araștırmaları Dergisi 8:15 (Ağustos 2018), s.1452.

28 Teoman Akpınar, “Türkiye'deki Suriyeli Mülteci Çocukların ve Kadınların Sosyal Politika Bağlamında Yaşadıkları Sorunlar," Balkan and Near Eastern Journal of Social Sciences 3:3 (2017), ss.1629; Aybiçe Tosun ve diğerleri, "Mülteci Öğrencilerin Eğitim Sorunları, Eğitim ve Din Eğitiminden Beklentileri: Eskișehir Örneği," Eskișehir Osmangazi Üniversitesi Sosyal Bilimler Dergisi 19:1 (2018), ss.107-133.

${ }^{29}$ Mehmet Akif Demir, “ïlköğretim Din Kültürü ve Ahlak Bilgisi Öğretmenliği Bölümü Öğrencilerinin Arapça Lisans Dersleri Hakkındaki Görüşleri: 19 Mayıs Üniversitesi İlahiyat Fakültesi Örneği," Cumhuriyet Üniversitesi Illahiyat Fakültesi Dergisi 18:1 (2014), ss.227-242; Yllmaz Çelik, "Arap Kökenli Öğrencilerin Yabancı Dil Olarak Türkçe Öğretiminde A Seviyesinde Yaptıkları Yazım Yanlışları ve Çözüm Önerileri," Anadolu Akademi Sosyal Bilimler Dergisi 1:1 (2007), ss.23-27; Tanrıkulu, "Türkiye'de Yașayan Suriyeli Çocukların Eğitim Sorunu ve Çözüm Önerileri," s.46; Kadir Kaan Büyükikiz ve Önder Çangal, "Suriyeli Misafir Öğrencilere Türkçe Öğretimi Projesi Üzerine Bir Değerlendirme," Uluslararası Türkçe Edebiyat Kültür Eğitim (TEKE) Dergisi 5:3 (2016), ss.1416-1418.
} 
Okullarda kronikleşen Suriyeli sorunu, belki de tüm kesimlerce artması istenmeyen önemli bir sorun alanıdır. Bunun yanında yalnızca sosyal sorunlar değil, din eğitimi ile ilgili sorunların da yaşandığı bilinmektedir. Bu açıdan din dersi öğretmenleri gibi Suriyeli öğrencilerle doğrudan temas eden ve temel dil yeterlikleri olduğu düşünülen öğretmenlerin yaşadıkları eğitimsel sorunların belirlenmesi de önem arz etmektedir. Din dersi öğretmenlerinin karşılaştığı sorunlara odaklanıp çözüm önerileri oluşturulması, kısıtlı bir çaba olarak görülse de okullarda yaşanan eğitim bilimsel sorunların görünür kılınması adına önemli bir girişimdir. Genel olarak literatürde Suriyeli öğrencilerin neden olduğu veya öğretmenlerin yaşadığı eğitsel sorunları belirlemeye çalışan sınırlı sayıda çalışma olduğu görülmektedir. Bu açıdan çalışmamız, literatürdeki önemli bir boşluğu doldurmanın yanında, yeni çalışma alanlarını belirginleştirecektir.

Bu araştırmada Suriyeli sığınmacı öğrencilerin eğitim gördüğü Milli Eğitim Bakanlığı Din Eğitimi Genel Müdürlüğüne bağlı imam hatip liselerinde çalışan din dersi öğretmenlerinin (din kültürü ve ahlak bilgisi ile imam hatip meslek dersleri) karşılaştıkları sorunlar ile bu sorunlara yönelik hangi çözüm önerilerini sunduklarının belirlenmesi amaçlanmaktadır. Araştırma kapsamında aşağıdaki sorulara yanıt aranmıştır:

Suriyeli sığınmacı öğrencilerin öğrenim gördüğü imam hatip liselerinde din dersi öğretmenleri, ders içinde ne gibi sorunlarla karşılaşmaktadır?

Suriyeli sığınmacı öğrencilerin öğrenim gördüğü imam hatip liselerinde din dersi öğretmenleri, okul içinde ne gibi sorunlarla karşılaşmaktadır?

Din dersi öğretmenlerine göre Suriyeli sığınmacı öğrenciler, imam hatip liselerindeki din derslerine karşı nasıl tutum sergilemektedir?

Okullarda karşılaşılan din eğitimi sorunlarının çözümüne yönelik din dersi öğretmenlerinin önerileri nelerdir?

\section{Yöntem}

\subsection{Araştırma Deseni}

Bu çalışmada, Suriyeli sığınmacı öğrencilerin öğrenim gördüğü imam hatip liselerinde din dersi öğretmenlerinin karşılaştıkları eğitim bilimsel sorunların yanında, bu okullarda öğrenim gören Türk öğrencilerin yaşayabileceği muhtemel sorunlar ve öğretmenlerin çözüm önerilerine yer verilmiştir. Araştırma ile eğitimsel sorunların detaylarına inilmesi hedeflendiğinden, nitel araştırma yöntemlerinin kullanılmasının uygun olacağına karar verilmiştir. Nitel araştırmalar, sosyal olgu ve olayları detaylı ve derin bir 
şekilde ele almaya imkan tanıyan araştırma desenlerine sahiptir. ${ }^{30} \mathrm{Bu}$ kapsamda çalışma nitel araştırma yöntemlerinden fenomenolojik araştırma yaklaşımı ile tasarlanmıştır. Fenomenolojik çalışmalar, gerçekte ortamda neler olduğuna bakma, sistematik bir biçimde verileri toplama, analiz etme ve sonuçları ortaya koyma yoludur. Ortaya çıan ürün ise, olayın niçin o şekilde olduğunun ve gelecek araştırmalar için daha detaylı olarak nelere odaklanmanın gerektiğinin keskin bir biçimde anlaşılmasıdır. Araştırma sürecinde kritik olayların doğası farklı sayıda örnek üzerinden keşfedilmeye çalışılacağından, keşfetmeye dayalı fenomenolojik analiz kullanılacaktır. $\mathrm{Bu}$ analiz yöntemi, kritik bir sorunu kendi bağlamında ele alan, olgular arasındaki sınırların muğlak olduğu, ortamda çoklu delil ve veri setinin bulunduğu durumlarda kullanılmaktadır. ${ }^{31}$

\section{2. Çalışma Grubu}

Araştırmanın çalışma grubu, 2018-2019 eğitim ve öğretim yılında, Ankara ilinin Altındağ, Mamak, Sincan, Çankaya, Yenimahalle ve Etimesgut ilçelerinde bulunan 17 imam hatip lisesinde çalışan din dersi öğretmeninden oluşmaktadır. Çalışma kapsamındaki okulların belirlenmesinde, Suriyeli öğrencilerin bu okullarda öğrenim görmesi ile en az 3 yll aktif olarak öğretmenlik yapma şartları arandığından nitel araştırma yöntemlerinden ölçüt örneklemesi kullanılmış, ayrıca kartopu örneklemesi kullanılarak veri toplanan öğretmenlerden farklı sorunlar yaşayan öğretmenlere ulaşılmıștır. Böylelikle bu araştırma kapsamında karma (hibrit) örnekleme yönteminin kullanılmasına karar verilmiştir. ${ }^{32}$ Çalışma grubunun sayısı belirlenirken verilerin farklılaşması prensibi esas alınmış, toplanan veriler doyuma ulaşana veya veriler birbirini tekrarlayana kadar yeni öğretmenler gruba dahil edilmiștir. Böylelikle 43 din dersi öğretmenine ulașılmıștır. Çalıșma grubunda yer alan öğretmenlerin 23'ü kadın 20'si erkektir. Veri toplanan 11 öğretmen, 1-5 yıl arası, 19 öğretmen 5-15 yıl arası, 13 öğretmen ise 15 yll ve üzeri mesleki kıdeme sahiptir. Öğretmenlerden 11'i DKAB lisans mezunu iken 32'si ilahiyat fakültesi mezunudur. Ayrıca 17 öğretmen alanında lisansüstü eğitim almıştır.

\footnotetext{
${ }^{30}$ Robert Bogdan ve Sari Knopp Biklen, Qualitative Research for Education (Boston: Allyn \& Bacon, 1997), s.53.

${ }^{31}$ Pamela Baxter ve Susan Jack, "Qualitative Case Study Methodology: Study Design and Implementation for Novice Researchers," The Qualitative Report 13:4 (2008), ss.544-559; Gareth Morgan ve Linda Smircich, "The Case for Qualitative Research," Academy of Management Review 5:4 (1980), ss.491-500.

32 Ali Baltacı, "Nitel Araştırmalarda Örnekleme Yöntemleri ve Örnek Hacmi Sorunsalı Üzerine Kavramsal Bir İnceleme," Bitlis Eren Üniversitesi Sosyal Bilimler Enstitüsü Dergisi 7:1 (2018), ss.231274.
} 


\subsection{Verilerin Toplanması}

Araştırma kapsamında maksimum verilerin toplanabilmesi için araştırmacılar tarafından hazırlanan ve açık uçlu sorulardan oluşan yarıyapılandırılmış görüşme formu kullanılmıştır. Yarı-yapılandırılmış görüşme formu taslağının geliştirilme aşamasında hazırlanan sorular, 4 din eğitimi, 2 program geliştirme, 2 ölçme ve değerlendirme, 1 Türk dili uzmanı ve 2 psikolojik danışmandan oluşan bir uzman grubuna sunulmuş ve alınan dönütlerle taslak ölçme aracı oluşturulmuştur. Taslak görüşme formu araştırma kapsamındaki çalışma grubunda olmayan ve Suriyeli öğrencilerin bulunduğu imam hatip liselerinde çalışan 5 din dersi öğretmenine sunularak soruların açıklığı ve uygulama geçerliği olup olmadığı konusunda görüş alınmıştır. Ön uygulama sonucunda geliştirilen taslak form, nitel araştırma yöntemlerine aşina 3 öğretim üyesine sunulmuş ve alınan dönütlerle formun son hali verilmiştir. Yarı-yapılandırılmış görüşme formu öğretmenlerin demografik bilgilerinin yer aldığı bölüm ile araştırma kapsamında ele alınan sorunsalı en iyi şekilde açıklamaya imkan tanıyacak soruların yer aldığı bölüm olmak üzere iki bölümden ve 10 sorudan oluşmaktadır.

Verilerin toplanmasında yapılandırılmış ve katılımlı görüşme yöntemi kullanılmıştır. Bu kapsamda Milli Eğitim Bakanlığından alınan etik ve uygulama izni ile birlikte okullara gidilmiş ve görüşmeler için özel bir oda (çoğunlukla okul idareci odası veya kütüphane) tahsis edilmesi sağlanmıştır. Görüşmelerde gönüllülük ilkesi aranmış, araştırma kapsamında görüşme yapmak istemeyen öğretmenlerden ziyade, bilgi vermeye istekli olan din dersi öğretmenleri seçilmiştir. Öğretmenlerle yapılan görüşmeler, öğretmenlerin boş zamanlarında yapılmış, görüşmelerin eğitim-öğretimi aksatmamasına gayret edilmiştir. Görüşmeler sırasında öğretmenlerden izin alınarak ses kayıt cihazı kullanılmış, ses kaydının yapılmasının istenmediği durumlarda notlar alınmıştır. Alınan notlar öğretmene okutularak kendi ifadesi dışında bir ekleme yapılmadığı teyit ettirilmiştir. Öğretmenlerle yapılan görüşmeler toplamda 117 saat 56 dakika; en uzun görüşme 4 saat 23 dakika, en kısa görüşme ise 2 saat 49 dakika sürmüştür.

\subsection{Verilerin Analizi}

Veri toplama aşamasında elde edilen veriler, hiçbir değiş̧iklik yapılmadan özel bir dikte programı ile yazıya dökülmüş; tekrarlı okuma ve dinleme faaliyetleri neticesinde ses kayıtları ile yazıya dökülen verilerin tutarlığı teyit edilmiştir. Verilerin analizinde içerik analizi yöntemlerinden MilesHuberman veri analizi tekniği kullanılmıștır. Bu teknikte veriler ayrıştırıl- 
makta ve tekrarlı okumalar ile belirli kodlamalar oluşturulmaktadır. ${ }^{33}$ Kodlamaların oluşturulmasında nitel içerik analizinde yaygın olarak tercih edilen Atlas.ti programı kullanılmış, ayrıca veriler el ile kodlanarak kodlama güvenirliği oluşturulmaya çalışılmıştır. Tümevarımsal kodlamalar sonucunda belirli sistematik kategoriler oluşturulmuş; kategorilerin birleşiminden çeşitli temalara ulaşılmıştır. Ulaşılan temalar, tümdengelimsel bir ayrıştırma ile yeniden kodlara ve kategorilere ayrıştırılmış, böylelikle kodlama işleminin güvenirliği sağlanmaya çalışılmıştır. Araştırmacıların yaptığı bu analizin güvenirliğinin sağlanması için, veri kodlama ve analiz işlemi nitel araştırmalara aşina 3 uzman kodlayıcı tarafından yinelenmiş ve araştırmanın kodlayıcı güvenirliği 0.86 olarak belirlenmiștir. ${ }^{34}$

\section{Bulgular}

Bu bölümde din dersi öğretmenlerinin görüşleri doğrultusunda şekillenen araştırma bulguları yer almaktadır. Veri analizi sonucunda (1) dil ve iletişim sorunları, (2) okul içi sorunlar, (3) okul dışı sorunlar, (4) din eğitimi ile ilgili sorunlar, (5) sosyal dışlanma ve önyargılar olmak üzere 5 tema belirlenmiştir. Ayrıca söz konusu temalara ilişkin din dersi öğretmenleri tarafından sunulan çözüm önerileri ayrı bir başlık altında incelenmiştir. İlerleyen bölümde din dersi öğretmenlerinin yaşadığı dil ve iletişim sorunlarını konu edinen temaya ait bulgular paylaşılacaktır.

\subsection{Dil ve İletişim Sorunları Temasına Ait Bulgular}

Din dersi öğretmenlerinin karşılaştığı dil ve iletişim sorunları temasına ilişkin bulgular Tablo 2'de incelenebilir.

Tema

Dil ve İletişim

Sorunları

Kategoriler

Sayı (n)

\begin{tabular}{|c|c|}
\hline Arapça bilmeme & 41 \\
\hline Suriyeli öğrencilerle iletişim kuramama & 32 \\
\hline Suriyeli velilerle iletişim kuramama & 29 \\
\hline $\begin{array}{l}\text { Suriyeli öğrencilerin Türkçe öğrenmeye } \\
\text { isteksiz olușu }\end{array}$ & 37 \\
\hline
\end{tabular}

Suriyeli öğrencilerle konuşurken anlaşılmama korkusu

Tablo 2: Dil ve İletişim Sorunları Temasına Ait İçerik Analizi Bulguları

\footnotetext{
${ }^{33}$ Matthew B. Miles ve A. Michael Huberman, Qualitative Data Analysis: An Expanded Sourcebook (New York: Sage Publications Inc., 1994).

${ }^{34}$ Lynne M. Connelly, "Trustworthiness in Qualitative Research," Medsurg Nursing 25:6 (2016), ss.435-437; Mariette Bengtsson, "How to Plan and Perform a Qualitative Study Using Content Analysis," NursingPlus Open 2 (2016), ss.8-14.
} 
Tablo 2'ye göre din dersi öğretmenlerinin büyük çoğunluğu $(n=41)$ Arapça bilmediklerini, Suriyeli öğrencilerle $(n=32)$ ve Suriyeli velilerle $(n=29)$ iletişim kuramadıklarını bildirmişlerdir. Ayrıca öğretmenler, Suriyeli öğrencilerin Türkçe öğrenmeye isteksiz olduğunu ( $n=37)$ ve onlarla iletişim kurarken anlaşılmayacaklarına yönelik korku yaşadıklarını $(n=26)$ dile getirmişlerdir. Konu ile ilgili öğretmen görüşlerinden bazıları aşağıda yer almaktadır:

... Din derslerinde Suriyeli öğrencilerle iletişim kurmakta zorlandığımız doğrudur. Derslerde Arapça konuşamıyoruz, çünkü lisans döneminde aldığımız Arapça dersler ilkokul seviyesindeydi. Ayrıca öğrenciler Türkçe öğrenmeye de oldukça isteksiz, geri dönmek de istemiyorlar. Nasıl olacak bilmiyorum? Ancak çat pat Türkçe konuşan öğrencilerin yardımıyla diğerleriyle anlaşıyoruz. Velilerle hiçbir ortak lisanımız yok, ne ben Arapça biliyorum ne de onlar Türkçe... Bir taraftan da benim az buçuk bildiğim Arapçayla dalga geçerler diye Türk öğrenciler karşısında Arapça konuşmaya korkuyorum... (DDÖ-19).

... Derslerde çoğunlukla tercüman kullanıyoruz, çünkü Suriyeliler bizim dilimizi öğrenmiyor; veliler de zaten onların Türkçe öğrenmesini istemiyor. Bu şekilde nasıl bir uyum sağlanacak bilmiyorum ama bir şekilde iletişim kuruyorum. Lisansta az bir şey Arapça öğrendim ama pratik olarak kullanamıyorum. Ayrıca Kur'an Arapçası ile Suriye lehçesi gerçekten çok farklı. Dil sorunu bence acil çözülmesi gereken önemli bir sorun... (DDÖ-39).

... Suriyeliler okul dişında sosyal hayata giremedikleri için Türkçe öğrenemiyorlar, bazıları dilencilik yaparken öğrenmiş Türkçeyi, zaten o çocuklar sayesinde diğeriyle iletişim kuruyoruz. Ben Arapça bilmiyorum. DKAB mezunu olunca Arapça ile temasınız az oluyor, ayrıca ne ben Arapça ne de onlar Türkçe öğrenmek istiyorlar... Zaten ben de onlarla iletişim kurayım diye zorlamıyorum kendimi, nasılsa ülkelerine dönecekler diye düşünüyordum ama dönmeyeceklerini anladım... (DDÖ-35).

\subsection{Okul İçi Sorunlar Temasına İlişkin Bulgular}

Din dersi öğretmenlerinin karşılaştığı okul içi sorunlar temasına ilişkin bulgular Tablo 3'de incelenebilir. 
Tema

Kategoriler

Sayı (n)

\begin{tabular}{lll}
\hline & Okul içi disiplinin bozulması & 43 \\
\cline { 2 - 3 } Okul İçi Sorunlar & \begin{tabular}{l} 
Okulda yaşanan temizlik ve düzen sorunları \\
\cline { 2 - 3 }
\end{tabular} & $\begin{array}{l}\text { Suriyelilerin okulun fiziki donanımına karşı } \\
\text { duyarsızlığı }\end{array}$ \\
\cline { 2 - 3 } & $\begin{array}{l}\text { Suriyelilerle ilgili okul yöneticileriyle yaşanan } \\
\text { sorunlar }\end{array}$ & 29
\end{tabular}

Tablo 3: Okul İçi Sorunlar Temasına Ait İçerik Analizi Bulguları

Tablo 3'e göre araştırmaya katılan din dersi öğretmenlerinin tamamı $(n=43)$ Suriyeli öğrencilerin okul içi disiplini bozduklarını düşünmektedirler. Ayrıca öğretmenler, okulda yaşanan temizlik ve düzen sorunlarını $(n=39)$, Suriyelilerin okulun fiziki donanımına karşı duyarsız oluşunu $(n=36)$ ve Suriyelilerle ilgili okul yöneticileriyle sorunlar yaşadıklarını $(n=29)$ ifade etmişlerdir. Konu ile ilgili öğretmen görüşlerinden bazıları aşağıda yer almaktadır:

... Suriyeliler geldikten sonra okul içinde düzen kalmadı. Türk öğrencilere karşı şiddet uyguluyorlar, misafir dedik, sığınmacı dedik ama Suriyelilerin yavuz hırsız olduğunu unutmamak gerekir. Okulun tüm disiplin işleri aksadı. Sınıflarda ders yapılamaz oldu, haraç kesmeler, adam yaralamalar, öğrenci dövmeler, öğretmenlere hakaret vb. olumsuz ne varsa hep Suriyelilerde toplanmış sanki. Okul içi düzen, disiplin maalesef daha da bozuluyor. Her geçen yıl öğrenci kalitesi bozuluyor... (DDÖ-11).

... Okulda düzensizlik hakim, temizlik ve disiplin de bozuldu. Ayrıca Suriyelilere her şey bedava verildiği için mala karşı aşırı duyarsızlar, okulun sıralarını parçalıyorlar ve biz sadece uyarıyoruz. Okulun camlarını kırıyorlar, biz sadece kınıyoruz. Okul içinde öğretmenlere hakaret, öğrencilere tacizde bulunuyorlar biz sadece okul değiștiriyoruz ki zaten bir yll sonra geri dönüyorlar. Suriyeliye kızsanız, iki kelam etseniz okul yönetimi başınıza biniyor. Müfettişler, avukatlar, STK'lar okul kapısında Suriyeli öğrenciye kötü davranan öğretmeni dava edip iki kuruş kazanmak için bekliyor... İşte durum bu, Suriyeli sığınmacı oldu başımıza Ankara valisi... (DDÖ-9).

... Suriyelilerin disiplinsiz ve urk gereği uyumsuz olduğunu biliyorum. Türkler gittikleri ülkelerde uyum sorunu yaşamazken Araplar asla değişmez. Dil bilmiyor, öğrenmeye isteksiz, yardım almak için okula geliyor ve burada yapmadı̆̆ rezillik yok. Disip- 
lin kalmadı okulda, sınıflara giremiyoruz. Bitli, pireli okula geliyor ve Türk öğrenciye de bulaştırıyorlar. Kızamık, verem, suçiçeği gibi hastalıklar yaygın; hatta geçen ay öğretmenlere bulaştı verem. Okulun lavabolarını kırıyorlar, kapıları tekmeliyorlar; ders işletmiyorlar... Nasıl bir sığınmacı anlamadım gitti... Okul yönetimi Suriyelileri kayırıyor, onların yaptıkları görmezden geliniyor; Suriyelileri uyarınca hemen biz de uyarllyoruz: "Hocam onlar misafirimiz, uyarmayın onları" diye... O kadar seviyorsan evine götür dedim idarecimize, uyarı cezamı aldım ve sustum... İşte durum bu, suçun cezasız kalması... (DDÖ-6).

\subsection{Okul Dışı Sorunlar Temasına Ait Bulgular}

Din dersi öğretmenlerinin karşılaştığı okul dışı sorunlar temasına ilişkin bulgular Tablo 4'te incelenebilir.

Tema

Kategoriler

Sayı (n)

\begin{tabular}{|c|c|c|}
\hline \multirow{5}{*}{$\begin{array}{l}\text { Okul Dişı } \\
\text { Sorunlar }\end{array}$} & Okulun güvenliğinin sağlanamaması & 39 \\
\hline & $\begin{array}{l}\text { Okul çevresinin Suriyeli öğrencilere karşı olumsuz } \\
\text { tutumu }\end{array}$ & 37 \\
\hline & $\begin{array}{l}\text { Suriyeli öğrencilerin kötü alışkanlıkları (alkol, sigara } \\
\text { vb.) }\end{array}$ & 35 \\
\hline & Suriyeli öğrencilerin radikalleșmesi & 30 \\
\hline & Suriyeli öğrencilerin karıștığı suc & 24 \\
\hline
\end{tabular}

Tablo 4: Okul Dışı Sorunlar Temasına Ait İçerik Analizi Bulguları

Tablo 4 incelendiğinde araştırmaya katılan din dersi öğretmenlerinin büyük çoğunluğunun $(n=39)$ Suriyeli öğrencilerin okulun dış güvenliğine bir tehdit oluşturduğunu düşündükleri görülmektedir. Ayrıca öğretmenler, okul çevresindeki halkın Suriyeli öğrencilere karşı olumsuz tutum sergilediğini $(n=37)$, Suriyeli öğrencilerin kötü alışkanlıkları olduğunu (n=35) ve Suriyeli öğrencilerden suça karışanların bulunduğunu ( $n=24)$ belirtmişlerdir. Bu noktada dikkat çeken bir bulgu da öğretmenlerin, Suriyeli öğrencilerin radikalleşmeye başladıklarına ilişkin ifadeleridir. Konu ile ilgili öğretmen görüşlerinden bazıları aşağıda yer almaktadır:

... Suriyeli öğrenciler okul içinde olduğu kadar dışında da toplum için, okul için bir tehdit kaynağıdır. Okulun dışında gruplar halinde geziyorlar, çevreyi rahatsız ediyor, sokakları kirletiyorlar. Esnafla kavga eden, yalnız yürüyen kızlara sarkıntılıkta bulunan öğrencilerimiz var, hem de imam hatip öğrencisi bunlar. Elbette Suriyeliler Türklere de kötü örnek oluyor. Onlara ceza verilme- 
diğini gören Türk öğrenciler de benzer davranışlar yapmaya başlıyor. Zaten okulda disiplin sağlanamadığından Suriyeliler bu kuralsızlık ortamını iyi kullanıyor. Alkol, sigara ve madde kullanan çok sayıda Suriyeli öğrenci var. Parklarda, okulun duvarının dibinde tüneyen, garip müzikler dinleyen, hırsızlık, gasp ve yankesicilik yapan imam hatip öğrencileri bunlar... Elbette polisin görevini yapıp yapmaması beni ilgilendirmez, ama yaşları küçük diye bu öğrencilere kimse dokunmuyor. Bunlar da toplum için birer tehdit olarak yetişiyorlar... (DDÖ-5).

... Birçok Suriyeli öğrencimiz, tarikat veya garip radikal oluşumlara meylediyor. Radikal gruplar derken çoğunlukla dinî radikallerden bahsediyorum. Aralarında seküler radikalleşmeye meyledenler de var. Çoğunluk buraya Arapça eğitim için geliyor ama zaten Arapça biliyorlar, imam hatiplerde Arap dilinin incelikleri öğretilmiyor ki... Suriyeliler, okulun güvenliği için sorun oluşturuyor. Hemen her gün polis çağırıyoruz. Okul içinde kavga etmeleri yetmezmiş gibi, bir de esnafa sataşıyor, esnafı haraca bağlamak istiyorlar. Madde bağımlığı olan çok sayıda imam hatipli Suriyeli var. Ayrıca ticaretini de yaptıklarını söylüyor Türk öğrenciler, polis sürekli kapıda ama bu ticaret ne hikmetse hala sürüyor... (DDÖ-26).

... Çevre halkı bizim Suriyelilerden şikayetçi; çünkü Suriyeli imam hatip öğrencileri okulun yanındaki sokağı parsellemiş, otopark gibi işletiyor; yani değnekçilik yapıyorlar. Okul dışına aracımızı park ediyoruz ve hemen her gün araçlarımızın lastiklerini inmiş, aynalarını kırılmış buluyoruz. Suriyelilerin yaptığı biliniyor, hatta failler belli ama ceza yok, çünkü kimse uğraşmak istemiyor. Okul içinde sataşmadıkları kişi kalmadı. En sessiz öğrencinin parasını almaktan tutun da okulun en fedai öğrencisini dahi sindirdiler. İnanılmaz bir toplumsal çöküntü yaklaşıyor Suriyeliler sayesinde... Okul içi yetmiyor sanki şimdi bu öğrenciler sokakta değnekçiliğe başladı, zaten çoğu iş saatleri dışında okula geliyor. Okul onlar için oyun, ders veya akademik başarı gibi dertleri de yok. Tek istedikleri, cinsel dürtülerini sergileyecekleri ortam, okulumuzun yanı park ve parkta yalnız bir kadın gördükleri anda hemen okuldan kaçıp kadını rahatsız ediyorlar. Polisi arasak da çözüm olmuyor. Okulumuzun güvenliğini sağlayamıyoruz. Bir öğretmenin çantasından maaşı çalındı, bir başka öğretmenimiz Suriyelilerce tehdit edildi... Yarın bir gün öldürülmeyeceğimiz ne belli... (DDÖ-11). 


\subsection{Din Eğitimi ile İlgili Sorunlar Temasına Ait Bulgular}

Din dersi öğretmenlerinin din eğitimi ile ilgili sorunlar temasına ilişkin görüşlerini içeren bulgular Tablo 5'te incelenebilir.

\begin{tabular}{llc}
\multicolumn{1}{c}{ Tema } & \multicolumn{1}{c}{ Kategoriler } & Sayı (n) \\
\hline & \multicolumn{1}{c}{ Suriyeli öğrencilerin dersin işlenişini sabote etmesi } & 43 \\
\cline { 2 - 3 } & $\begin{array}{l}\text { Suriyeli öğrencilerin mezhep farklılıklarını ön plana } \\
\text { çlkarmaları }\end{array}$ & 43 \\
\cline { 2 - 3 } $\begin{array}{l}\text { Ein } \\
\text { Eğitimi }\end{array}$ & $\begin{array}{l}\text { Suriyeli öğrenciler ile Türk öğrenciler arasındaki akade- } \\
\text { Silk seviye farkı }\end{array}$ & 41 \\
\cline { 2 - 3 } \begin{tabular}{l} 
Sorunlar \\
\cline { 2 - 3 }
\end{tabular} & Suriyeli öğrencilerin din derslerine karşı ilgisizliği & 40 \\
\cline { 2 - 3 } & Suriyeli öğrencilerin din derslerine karşı olumsuz tavrı & 40 \\
\cline { 2 - 3 } & Suriye ve Türkiye'deki din öğretimi müfredatı farklılı̆̆ı & 39
\end{tabular}

Tablo 5: Din Eğitimi ile İlgili Sorunlar Temasına Ait İçerik Analizi Bulguları

Tablo 5 incelendiğinde, Suriyeli öğrencilerin din derslerini anlayamaması, Suriyeli öğrencilerin dersin işlenişini sabote etmesi ve Suriyelilerin mezhepsel farklılıkları ön plana çıkarması öğretmenlerin tamamı tarafından $(n=43)$ bildirilen sorunlardandır. Ayrıca öğretmenler, Suriyeli öğrencilerin okuma-yazma sorunlarının olduğunu $(n=41)$ ve Türk ve Suriyeli öğrenciler arasında Türk öğrenciler lehine akademik seviye farklılığı bulunduğunu ( $\mathrm{n}=41)$ belirtmektedirler. Bunun yanında din derslerine karşı ilgisizlik $(n=40)$, din derslerine karşı olumsuz tavır $(n=40)$ ve her iki ülke arasındaki müfredat farklılığı $(n=39)$ öğretmenlerin üzerinde durduğu din eğitimi sorunları arasındadır. Katılımcıların din eğitimi teması kapsamında ileri sürdüğü görüşlerden bazıları aşağıda özetlenmiștir:

...Suriyeli öğrenciler, Türkçe anlatılan bir din dersini anlayamıyorlar. Örneğin ben tefsir ve hadis anlatıyorum. Bir nebze şanslı olduğumu düşünürdüm. Ancak sadece Arapça hadis ve ayet okuduğumda anlıyor öğrenci, Türkçe açıllamaya başladığımda sıranın üzerine yatıyor veya dersle ilgilenmeyi bırakıyor ya da öğrenci dersi sabote ediyor. Aslında dil bilse sorun çözülecek ama Türkçe öğrenmeye de gayreti yok. Bir de Suriyeliler kendilerini daha dindar vs. görüyorlar, Türkiye'yi seküler, laik bir ülke gibi gördüklerinden bizim din derslerimizin aslında bir sekülerleştirme süreci olduğuna inanıyorlar. Çoğu bizi tekfir ediyor, yani dinsizlikle suçluyor. Kendi mezheplerinin üstünlüklerini anlatıyor ve radikal gruplara övgüler yağdırıyorlar... Suriye'deki din eğitimini bilmiyorum ama sanırım medrese kültürü hakim, bu- 
rada devlet eliyle verilen din dersini kabullenememe nedenleri belki de budur... (DDÖ-22).

...Suriyeli öğrencilerle bizim din derslerimizin yıldızı bir türlü barışmadı. Derse karşı çok olumsuz tavırları var, muhtemelen müfredat farkı var ve belki de en önemlisi dil bilmemek, okuyup yazamamak. Bu yüzden Türk öğrencilerle aralarında akademik yönden bir fark oluşuyor. Çoğu derste başarısızlar, zaten başarı beklemek de mümkün değil. Suriye nesillerini kaybediyor. Bizim nüfus zaten yoğun ama onları kazanmamız gerekiyor bir şekilde. Din eğitimi bunun belki de en kolay yolu diye düşünürdüm. Ancak özellikle radikal gruplar ve tarikatlar tarafından ele geçiriliyor Suriyeliler, ele geçirilince toplumumuz için daha da tehlikeli oluyorlar... Benim din derslerimin 15-20 dakikası Suriyelilere nasihat ederek geçiyor. Belki 10-15 dakika da kızıyorum onlara dersi kestikleri, arkadaşlarının dikkatini dağıttıkları için, çünkü olur olmaz ergenlik peşindeler ve dersimi sabote ediyorlar... Suriye'ye döneceklerini sanmadığımdan onlara iyi bir din eğitimi vermek istiyorum ama kendi mezheplerinin öğretilerini bizim ders kitaplarından üstte tutuyorlar. Türklerden nefret edenler de var, hatta Türk milletinin değerleri ile alay edenler de... Arap milliyetçiliğini her şeyin üstünde tutuyorlar; Arapça bilmemeyi bir eksiklik olarak görüyorlar. Kendilerini ötekileştirdiklerinin de farkında değiller. Akılları nargile içip simit kafede oturmakta olan bir imam hatipli Suriyeli nesil geliyorken bizim hala bir şeyler yapamaz olmamız ne acı... (DDÖ-7).

...Kur'an-ı Kerim derslerinde sorun yaşamıorum ama fikıh ve kelamda ciddi sorunlar var. Çünkü dilimizi bilmiyor ve dersi anlamıyorlar, dersi anlamayınca sıkılıyor ve diğer öğrencileri rahatsız etmeye, garip sesler çıkarmaya, Arapça şarkılar söylemeye başlıyorlar. Çoğunluğu dine karşı ilgili olsa da çarpık bir din anlayışları var. Düzeltemiyorum çünkü benim Arapçam yok. Ama veliler de daha fazlasını istemiyor zaten, Kur'an okusun yeter diyorlar. Öğrenciler din derslerine karşı zaten ilgisiz, ödev versen ödevi yapmıyor; oku diyorsun okuma bilmiyor. Dine ilgili, din derslerini seven, çat pat Türkçe konuşan hafız öğrencilerimiz vardı, aileleri okuldan alıp işe verdi. 16-17 yaşında evlendirilenler oldu, okumak onlar için bir seçenek değil; zaten akademik başarıları da sınırlı, Türk öğrencilerin seviyesine gelmeleri uzun zaman alır. Hele bizim onlar için din öğretimi metotları falan geliştirmemiz 25-30 yılı bulur. Ama ne varsa dinde var! Ben dinî bir eğitimle bu öğrencilerin kazanılabileceğini düşünü- 
yorum. Onları kazanalım diye Türkleri unutmazsak iyidir... (DDÖ-33).

\subsection{Sosyal Dışlanma ve Önyargılar Temasına Ait Bulgular}

Din dersi öğretmenlerinin sosyal dışlanma ve önyargılar temasına ilişkin görüşlerini içeren bulgular Tablo 6'da incelenebilir.

\begin{tabular}{|c|c|c|}
\hline Tema & Kategoriler & Sayı (n) \\
\hline \multirow{6}{*}{$\begin{array}{l}\text { Sosyal } \\
\text { Dişlanma } \\
\text { ve Önyargl- } \\
\text { lar }\end{array}$} & Suriyeli öğrencilerin okul içinde dışlanması & 43 \\
\hline & $\begin{array}{l}\text { Yalnızca Suriyeli veya Arapça bilen öğrencilerle arka- } \\
\text { daşlık kurma }\end{array}$ & 42 \\
\hline & $\begin{array}{l}\text { Suriyelilere yönelik toplumsal gerginlikler ve onları } \\
\text { Türkiye'de istememe }\end{array}$ & 42 \\
\hline & Suriyelilere yönelik toplumsal önyargılar & 40 \\
\hline & Suriyelilerin Türklere karşı önyargılı oluşu & 37 \\
\hline & $\begin{array}{l}\text { Toplumda Suriyelilere yönelik genel bir güvensizlik } \\
\text { olması }\end{array}$ & 36 \\
\hline
\end{tabular}

Tablo 6: Sosyal Dışlanma ve Önyargılar Temasına Ait İçerik Analizi Bulguları

Tablo 6'ya göre din dersi öğretmenlerinin tamamı (n=43), imam hatip liselerinde öğrenim gören Suriyeli öğrencilerin okul içinde dışlandığını düşünmektedir. Öğretmenlerin çoğunluğu, Suriyeli öğrencilerin yalnızca Suriyeli veya Arapça bilen öğrencilerle arkadaşllk kurduğunu $(n=42)$ ve toplumda Suriyelilere yönelik toplumsal gerginlikler yaşandığını, Suriyelilerin Türkiye'de istenmediğini $(n=42)$ de dile getirmişlerdir. Bununla birlikte din dersi öğretmenleri, Suriyelilere yönelik toplumsal önyargılar $(n=40)$ olmasına karşın Suriyelilerin de Türklere karşı önyargılı olduklarını (n=37) bildirmiş, Suriyelilere güvenmediklerini ve toplumda da bu güvenin düşük olduğunu $(n=36)$ ifade etmişlerdir. Konu ile ilgili öğretmen görüşlerinden bazıları aşağıda yer almaktadır:

... Suriyeli öğrenciler okul içinde gruplar halinde dolaşıyor, aynı dili konuşan diğer ülke vatandaşlarıyla da arkadaşlık kurabiliyor. Ancak çok azı Türkler tarafından kabul ediliyor. Misafirperver olsak da toplumda yoğun bir gerilim var; toplumun böyle davranmasını anlayışla karşılamak gerek, şöyle ki Suriyelilerin temel hizmetleri bedava alması, ilaca, elektriğe para ödememesi ve vergi vermemesi gibi şeyler üst üste gelince halk doğal olarak dışlıyor onları. Ayrıca Suriyeliler yıllarca Osmanlıya düşman olmuş, Osmanlıyı kendilerini sömüren bir emperyalist güç olarak 
öğrenmiş, şimdi birden Türklerle bir arada yaşamak zorunda kalmaları duygusal bir yıkım onlar için. Kurtuluş savaşında Arapların Osmanlıya yaptığını da unutmamak gerek, ben Araplara önyargılıyım. Ülkelerine dönmeleri gerekiyor... (DDÖ-15).

...Toplumda ve okulda Suriyelilere yönelik yoğun bir güvensizlik var, ülke onlara karşı önyargıll. Şehirlerde aylak aylak gezen ve maaş alan bu güruhun belki de en önemli işlevi kültürümüze nargile gibi gereksiz bir şeyi yerleştirmek. Öğrencilerimizin nargile kafelerde zaman geçiriyor olması çok üzücü, biz onlara önyargılıyız ama onlar da bize karşı güvensiz. Savaştan sığındıkları ülkede ev sahibi gibi yaşayan, istediklerini yapan ve ceza veya yaptırımla karşılaşmayan Suriyeliler, hiçbir şekilde Türkiye'ye uyum sağlamaya çalışmıyor. Bu uyumsuzluk onların okul içinde dışlanmasına neden oluyor. Öğretmenler Suriyelilerin olduğu sınıflara nefretle giriyor, bu sınıflarda büyük disiplin sorunları var. Suriyeliler kural tanımıyor, akademik olarak ilgisiz ve dersin işlenmesini engelliyorlar, zamanla ben de onlara karşı önyargı oluşturdum. Toplumdaki gerginliğin nedenlerini anlarsak, onların neden geldiğini ve neden dönmediğini de anlayabiliriz. Burada rahat şartlarda yaşıyorlar, kimse onlara hesap soramıyor, hesap sorsak soruşturma geçiriyoruz. Eğitim sistemi Suriyeleşiyor... (DDÖ-42).

...öğrenciler ve öğretmenlerin çoğu Suriyelileri sevmiyor, onları okulda istemiyor. Suriyeliler de okula devam etmek istemiyorlar. Eğitimden beklentileri yok; öğretmenleri, kendilerini engellemeye çalışan ve özgürlüklerini kısıtlayan gardiyanlar gibi görüyorlar. Toplum Suriyelilerin dönmesini istiyor. Belki Ankara'da Suriyeli sayısı Hatay veya Kilis gibi çok değil ama burada bile kültürümüzü olumsuz etkiliyorlar. Öğrencilerimiz, Suriyelilerin gelişiyle okulun disiplinsiz, kuralsız ve değersiz bir yapıya evirildiğini söylüyor. Haksız da değiller... Karşılıklı önyargılarımız var, ülkelerini terk etmek zorunda kalmaları üzücü ama Türkiye'de sorun kaynağı haline gelmeleri daha da üzücü... (DDÖ-21).

\subsection{Din Dersi Öğretmenleri Tarafından Önerilen Çözümlere İliş̧kin Bulgular}

Din dersi öğretmenlerinin önerilerine ilişkin görüşlerini içeren bulgular Tablo 7'de incelenebilir. 
Tema

Kategoriler

Sayı (n)

\begin{tabular}{lll}
\hline & Türkçe eğitimi & 43 \\
\cline { 2 - 3 } & Önyargıların azaltılması için empati eğitimi & 42 \\
\cline { 2 - 3 } & $\begin{array}{l}\text { Suriyelilerin Türklerden ayrılarak farklı okullarda } \\
\text { anadilinde eğitim alması }\end{array}$ & 41 \\
\cline { 2 - 3 } Öneriler & $\begin{array}{l}\text { Daha etkin psikolojik rehberlik hizmetleri ile sosyal } \\
\text { çalışmalar }\end{array}$ & 40 \\
\hline $\begin{array}{l}\text { Suriyelilere yönelik sosyal uyum faaliyetlerinin arttı- } \\
\text { rllması }\end{array}$ & 37 \\
\cline { 2 - 3 } & Velilerin Türkiye’ye uyumunun sağlanması & 35 \\
\cline { 2 - 3 } & Öğretmen ve öğrenciler için temel Arapça eğitimi & 22
\end{tabular}

Tablo 7: Önerilere Ait İçerik Analizi Bulguları

Tablo 7 incelendiğinde, din dersi öğretmenlerinin tamamı $(n=43)$, Suriyelilerin Türkçe eğitim almasını önermektedir. Ayrıca toplumda ve okuldaki önyargıların azaltılması için empati eğitimi yapılması gerektiğini öneren öğretmenler, daha etkin psikolojik rehberlik hizmetleri ile sosyal çalışmaların, okullarda yaşanan sorunları azaltabileceğini belirtmişlerdir. Bununla birlikte öğretmenlerin büyük çoğunluğu $(n=41)$, Suriyelilerin anadillerinde ve Türk öğrencilerden ayrılarak eğitim almasını önermektedir. Suriyelilere yönelik sosyal uyum faaliyetlerinin arttırılması ( $n=37)$, velilerin Türkiye'ye uyumu için çalışmalar yapılması $(n=35)$ gibi öneriler de söz konusudur. Din dersi öğretmenlerinin sorunların çözümü için diğer bir önerisi ise Türk öğretmen ve öğrencilere yönelik temel Arapça eğitiminin verilmesidir $(n=22)$. Konu ile ilgili öğretmen önerilerinden bazıları aşağıda yer almaktadir:

...Açıkçası dil eğitimi belki de en önemli sorun, kesinlikle Türkçe kursları açılmalıdır. Ayrıca ilk okuma-yazma dersleri verilebilir. Okullarda ders çıkışlarında etütler yapılıp yazma kursları düzenlenebilir. Tahtaya yazdığınız veya slaytta gördükleri şeyleri yazıyorlar ama resim çizer gibi yazıyorlar, anlayarak yazamıyor; adını dahi Latin harfleri ile yazamıyor... (DDÖ-28).

...Ben şahsen onlara karşı önyargllıyım. Çünkü yeterince deneyim yaşadım Suriyeliler hakkında. Okul ve toplumda önyargının azaltılması, gerginliğin düşürülmesi gerekiyor. Giderek onları şeytanlaştırıyoruz. Empati eğitimleri verilebilir. Onlar bizi, biz onları daha iyi anlarız. Okullarda veya toplumda madem beraber yaşayacağız, çalışacağız, birbirimizin duygularını anlamalıyız. Ahlak olarak çok zayıflar, dinen sorunlu inançları var; bizi kabul 
etmiyorlar, biz de onları kabul etmiyoruz. Bu açıdan empati çözüm olabilir... (DDÖ-35).

...Suriyeliler okuldaki kaynaştırma öğrencileri gibi, kimse onlarla iletişim kurmuyor. Kaynaşamıyorlar, onlara özel olarak hazırlanmış eğitim merkezleri kurulmalı. Eğitim merkezlerinde anadillerinde eğitim almalılar. Böylece Türk öğrencilerin okullarda dışladığı Suriyeli olarak hayatlarına devam etmektense, kendilerini önemli hissettikleri okullara gidip yeni bir hayat kurabilirler... (DDÖ-31).

...Suriyeliler neden Türkçe öğrenmiyorlar, neden ülkelerine dönmüyorlar deyip duracağımıza onların topluma uyumunu sağlamalıyız. Onlara Türkçe öğrenmenin zorunluluk olduğunu, topluma uyum sağlamadan burada kalamayacaklarını açıklamalıyız. Sosyal uyum programları ile beraber yaşamanın anlamını, birlikte üretebileceğimizi göstermeliyiz. Velilere ulaşarak başlayabiliriz. Ancak bu bireysel çabalar, okyanusta damladır. MEB bunlara önderlik edecek, projeler yapacak ve öğretmenleri eğitecek. Sonra öğretmenler, Suriyeli velilere ulaşacak ve onların topluma uyum sağlamalarına yardımcı olacaklar. Veliler uyum sağlarsa, öğrenci de sağlar... (DDÖ-38).

...Evet, onlar Türkçe öğrenmek istemiyor, kültürlerini korumak istiyorlar ama biz Arapça öğrenebiliriz. Önyargıyı kırmanın en iyi yolu onlarla zaman geçirmektir. Siz hiç Hintçe, Malayca veya Arapça öğrenen bir emperyalist İngiliz gördünüz mü? Göremezsiniz, çünkü İngilizler dillerini öğretir ve bunu zorunlu kılar, hem kendi ülkesinde hem kolonisinde sadece İngilizce konuştururlar. Osmanlı bunu yapmadı, yapmak istemedi. Bunun için Osmanlı'ya emperyalist güç diyen Araplar yanılıyor. Ama şimdi biz aynı Osmanlı'nın yaptığı gibi Arapça öğrenebiliriz. Arapça öğrenmek kültürümüzden kaçış veya kopuş değil, sayıları milyonları bulan Araplarla temas edebilmek, onların topluma uyumunun mümkün olabileceğini göstermek. Bu açıdan ben herkesin Arapça öğrenmesinin zorunluluk olduğunu düşünüyorum... (DDÖ-40).

\section{Tartışma, Sonuç ve Öneriler}

Son dönemlerde önemli sayıda göç alan Türkiye, göçle beraber beliren sorunlarla yüzleşmek zorundadır. Karmaşık göç olgusunun yarattığı sorunlardan belki de en önemlisi, göçmen veya sığınmacı çocukların eğitimidir. Türkiye'de en fazla sığınmacının Suriye kökenliler olduğu düşünüldüğünde gündelik yaşamda "Suriyeliler sorunu" olarak dillendirilen bu olgunun farklı alanlarda yeni "Suriyeli" sorunlar açması olasıdır. Eğitim sistemi içinde 
önemli sayıda Suriye kökenli öğrenci olması, bu sorunun eğitimdeki adını "Suriyelilerin eğitimi sorunu" olarak belirginleștirecektir. Türk eğitim sistemi, içinde, Suriyelilerin eğitimi sorununu çözümlemek için çeşitli genel politikalar üretmiş olsa da yerel düzeyde farklı ve esnek politikaların henüz üretilemediği ve yerel düzlemde Suriyeli öğrenci sorununun katlanarak arttığı görülmektedir. Bu araştırma sonuçlarına göre imam hatip liselerinde okul içi ve okul dişı, din eğitiminin sunumu ve sosyal dişlanma gibi sorun alanları belirlenmiştir. Elbette bu sorun tasnifi din dersi öğretmenlerinin görüşlerine göre belirginleşmiş olup giderek kronik bir hal almaya başlayan Suriyeli öğrenci sorunsalının görünürlügünü artırmıştır.

Araştırma sonuçlarına göre din dersi öğretmenlerinin imam hatip liselerinde yaşadıkları temel sorunlar dil ve iletişim sorunları ile okul içi disiplinin sağlanamaması ve okulda genel düzensizliğin olmasıdır. Araștırmanın bu sonucu literatürdeki çok sayıda çalışma ile benzerlik göstermektedir. Literatürde farklı türden araştırmalarda göçmen veya sığınmacı öğrencilerin Türkçe bilmedikleri için okullarda çeşitli sorunlar yaşadıkları bildirilmektedir. ${ }^{35}$ İmam hatip liselerindeki Suriyeli öğrenciler Türkçe bilmediklerinden gerek sınıf arkadaşları gerekse öğretmenler ile iletişim kuramamakta, okul içi kurallara uymamakta veya okulun genel düzenini bozacak davranışlarda bulunabilmektedir. İmam hatip lisesi yöneticilerinin Suriyeli öğrencilere yönelik pozitif ayrımcılık yaptığı veya Suriyeli öğrencilerin işlediği suçların görmezden gelindiğine yönelik araștırma bulgusu önemlidir. Oysa eğitim sistemindeki her öğrenci eşit düzeydedir. Misafir öğrenci olsalar da okulun eşyalarına zarar veren veya okul içi düzeni bozan öğrencilerin uyarılması ve zarar gören eşyanın tazmin ettirilmesi, adaletli yönetim için önemli bir ilkedir. Okullarda böylesi ayrımcılıkların yaşanması, toplumsal hafızada derin ayrışmalar açabilir.

Araştırma sonuçlarına göre Suriyeli öğrenciler okul dışında güvenlik temalı sorunlar üretebilmektedirler. Araştırmanın bu sonucu literatürdeki

\footnotetext{
35 Aykırı, "Sınıf Öğretmenlerinin Sınıflarındaki Suriyeli Öğrencilerin Eğitim Durumlarına İlişkin Görüșleri," ss.36-39; Erdem, "Sınıfında Mülteci Öğrenci Bulunan Sınıf Öğretmenlerinin Yașadıkları Öğretimsel Sorunlar ve Çözüme Dair Önerileri," ss.32-34; Kartal, "Türkiye'ye Yönelik Suriyeli Göçünün Çok Yönlü Doğasına Giriş," ss.15-17; Emin, Türkiye'deki Suriyeli Çocukların Eğitimi: Temel Eğitim Politikaları, ss.24-29; Büyükikiz ve Çangal, "Suriyeli Misafir Öğrencilere Türkçe Öğretimi Projesi Üzerine Bir Değerlendirme," ss.1423-1424; Akpınar, "Türkiye’deki Suriyeli Mülteci Çocukların ve Kadınların Sosyal Politika Bağlamında Yaşadıkları Sorunlar," ss.42-49; Canyurt, "Suriye Gelişmeleri Sonrası Suriyeli Mülteciler," s.139.
} 
farklı araştırmalarla desteklenmektedir. ${ }^{36}$ Okulun güvenliğini tehdit eden, okul çevresini istikrarsızlaştıran ve suça karışan Suriyeli imam hatip öğrencilerinin halen eğitim sisteminde bulunduğu bilgisi önem arz etmektedir. Okulun güvenliği çoğu durumda güvenlik güçlerince veya güvenlik hizmet alımı ile karşılanmaktadır. Ancak okulun bulunduğu çevrenin güvenli hale getirilmesi için öğrencilerin suçlara karşı bilinçlendirilmesi ve zararlı alışkanlıklardan uzaklaştırılması gereklidir. Okulu güvenli hale getirmek için Suriyeli öğrencilere yönelik sosyal politikalar geliştirilmeli ve onların toplum için bir tehdide dönüşmeden toplumsal sisteme eklemlenmeleri gereklidir. Ayrıca bu araştırma ile Suriyeli imam hatip lisesi öğrencilerinin önemli bir kısmının sigara, alkol ve uyuşturucu madde gibi bağımlılıkları olduğu ve uyuşturucu madde ticaretiyle ilgilendiği, çoğu öğrencinin ders dişında kaçak olarak çalıştığı belirlenmiştir. Bu durumun engellenmesi öğretmen veya okul yöneticisinin sorumluluk sınırlarını aşan ve oldukça karmaşık politika ve önlemleri gerektirir. Ayrıca çoğu Suriyeli öğrencinin okul çevresindeki esnaf ve yerel halkla sorunlar yaşadığı, haraç, yankesicilik ve hırsızlık gibi suçlara karıştıkları da bu araştırma ile belirlenmiş olup sorunun çözümü için çok taraflı bir önlem paketi gerekli görülmektedir.

Araştırma sonucuna göre Suriyeli öğrencilerin din eğitimine ilişkin sorun kaynakları çeşitlilik arz etmektedir. Suriyeli öğrenciler, derslerde işlenen din eğitimi konularını anlayamamaktadırlar. Bu durum öğrencilerin Türkçe bilmemesi ile açılanabilir. Türkçe bilmeyen öğrenciler derslerde sıkılmakta ve dersin işlenişini sabote edebilmektedirler. Söz konusu bulgular literatürdeki farklı araştırmalarla paralellik göstermektedir. ${ }^{37}$ Örneğin Kızılabdullah ve Yürük, öğretmenlerin karşılaştığı en yaygın sorunun dil eksiklikleri olduğunu; bu durumun sınıf içinde ve dişında Suriyeli öğrenciler için önemli bir iletişim engeli oluşturduğunu belirlemişlerdir. ${ }^{38}$ Dersin işlenişine göre Suriyeli öğrencilere sorumluluk vermek, dersin belirli bölümlerinde onları derse katacak etkinlikler tasarlamakla bu sorun aşılabilir. Din eğitimi dersleri, doğası gereği Arapçaya yakındır; özellikle Kur’an-ı Ke-

\footnotetext{
${ }^{36}$ Şimşek, “Göç Politikaları ve 'İnsan Güvenliği'," ss.13-15; Tanrıkulu, “Türkiye'de Yaşayan Suriyeli Çocukların Eğitim Sorunu ve Çözüm Önerileri," ss.26-27; Kap, "Suriyeli Mülteciler: Türkiye'nin Müstakbel Vatandaşları," s.33.

37 Çelik, "Arap Kökenli Öğrencilerin Yabancı Dil Olarak Türkçe Öğretimi," ss.24-25; Tok ve Yıgın, "Yabancı Uyruklu Öğrencilerin Türkçe Öğrenme Nedenlerine İlișkin Bir Durum Çalışması," s.144; Canyurt, "Suriye Gelişmeleri Sonrası Suriyeli Mülteciler," s.53; Șeker ve diğerleri, Göç ve Uyum, ss.12-19.

38 Yildiz Kizilabdullah ve Tugrul Yuruk, "The Contribution of the Religious Culture and Ethics Course on the Integration of Children of Syrians in Adana, Turkey," Religious Education 113:3 (2018), ss.289-301.
} 
rim derslerinde Suriyeli öğrencilere aktif rol verilerek derse katılımları sağlanmalıdır. Suriyeli öğrencilerin anadili Arapça olduğundan Arapça derslerinde de benzer görevler verilebilir. Akran öğrenmesi metodu gibi aktif öğrenmelerle Türk öğrencilerin, Suriyeli öğrencilerden dil ve Kur'an okumanın inceliklerini öğrenmeleri teşvik edilebilir. Bu araştırmayla daha da belirgin hale gelen, Suriyeli öğrencilerin mezhepsel farklılıkları ön plana çıkardıkları bilgisi önemlidir. Halen bir iç savaş yaşayan ülkede, savaşın taraflarının farklı mezheplerden gruplar olduğu bilindiğinden, böylesi bir olgu zaman geçirilmeden üst makamlara bildirilmeli, öğrencilerin bu fikirleri uzmanlar tarafından dikkatle değerlendirilmelidir. Araştırma sonuçlarından biri de Suriyeli öğrencilerin okuma-yazma bilmemeleri ve kendilerine gösterilen metinleri, resim kopyalar gibi kopya ettikleridir. Bu sorun okullarda açılacak okuma-yazma kursları ile rahatlıkla giderilebilir. Ayrıca okullarda çeşitli projeler kapsamında devam eden dil kursları, yetişkin ve öğrenciler için uyum programları da vardır. Bu programlara öğrencilerin erişiminin sağlanması ise öğretmen ve okul yöneticilerinin sorumluluğundadır. Bu açıdan okul içi iletişim mekanizmaları geliştirilmeli ve Suriyeli öğrencilerin lehine olan eğitim fırsatlarından yararlanmaları sağlanmalıdır.

Araştırma sonuçları arasında yer alan Suriyeli öğrencilerin din derslerine karşı olumsuz tavır sergilemesi ile din derslerine karşı ilgisizlik, önemli bulgulardır. Ayrıca araştırmada din dersi öğretmenlerinin büyük çoğunluğu Suriye ve Türkiye arasında din öğretimi müfredatından kaynaklanan farklılaşma olduğunu da bildirmiştir. Suriyeli öğrencilerin din derslerine karşı olumsuz tutum sergilemesi, çoğu durumda farklı mezhebî veya inanç dizgesine sahip olabileceklerini akla getirmektedir. Ayrıca Türkiye'nin laik bir sisteme sahip olması Arap coğrafyasında yıllar boyu olumsuz propaganda aracı olarak kullanılmış, Arap halkları Türkiye'nin İslam karşıtı bir ülke olduğuna dair yoğun bilgi çarpıtmalarına maruz bırakılmıştır. Böylesi bir deneyime sahip olan Suriyeli öğrencilerin Türkiye'deki din derslerine ihtiyatlı yaklaşmaları olasılık dahilindedir. Ancak din dersi öğretmenlerinin bu duruma engel olmaları ve din derslerini sığınmacı öğrencilere sevdirmeleri gerekmektedir. $\mathrm{Bu}$ açıdan derslerde uygulamalı etkinliklere yer verilerek öğrencilerin ilgisi çekilmeye çalışılabilir; derslerde dualar veya Kur'an ayetleri bu öğrencilere okutularak onların eğilimlerine yön verilebilir. Araștırma kapsamında açığa çıkarılan bir diğer bulgu olan Suriye ve Türkiye arasındaki din öğretimi müfredat farklılığıdır. Gerçekten de her iki ülke arasın- 
da önemli bir farklılık söz konusudur. ${ }^{39}$ Türkiye'de din öğretimi müfredatı kültürlerarası ve değer yönelimli iken, Suriye'de yerel inançlar temel alınarak hazırlanan dine dayalı eğitim söz konusudur. Dine dayalı eğitimde belirli bir dinin inanç ve ibadetleri öğretilirken, kültürlerarası ve değer yönelimli anlayışta farklı dinler ve kültürler tanıtılıp öğrencilere ortak kök değerler kazandırılmaya çalışılmaktadır. ${ }^{40} \mathrm{Bu}$ yaklaşım farklılığını gidermek için din dersi öğretmenlerinin Suriyeli öğrenciler için dinî veya manevi ihtiyaç analizi yapması ve elde ettiği verilere göre bireysel yönelimli din eğitimi sunması önerilebilir.

Araştırma sonuçlarına göre Suriyeli öğrenciler okulda dişlanmakta, yalnızca Suriyelilerle veya Arapça konuşan öğrencilerle arkadaşlık kurmaktadırlar. Dışlanma, yeni bir ortama giren yabancıların sıklıkla yaşadığı sorun olarak literatürde yer almaktadır. ${ }^{41}$ Ayrıca yabancı bir ortama giren bireyler, bir şekilde iletişim kurabilecekleri ve aynı dili konuşan kişileri aramakta ve doğal olarak sosyal alanda özerk bir grup oluşturmaktadırlar. Bu araştırmanın dikkat çekici bulgusu Suriyeli öğrencilere yönelik artan sosyal gerginlik ve önyargllardır. Gerek Suriyeli öğrencilerin Türklere gerekse Türk öğrenci ve öğretmenlerin Suriyelilere karşı geliştirdikleri önyargılar, birlikte yaşama kültürünü zedelemektedir. Suriyeli öğrencilerin Türk ve Osmanlı önyargısı çoğunlukla geçmiş deneyim ve siyasi çarpıtmaların sonucudur. Oysa Türk öğrenci ve öğretmenlerin önyargıları bireysel yaşanmışlıklar ve Suriyelilerin toplumsal alanda giderek belirginleșen suç olayları ve Suriyelilere karşı gösterilen aşırı müsamahakar politikaların sonucudur. ${ }^{42}$ $\mathrm{Ne}$ şekilde geliştiğine dikkat edilmeksizin her tür önyargı, yalnızca birlikte yaşayarak ve ötekini tanıyarak giderilebilir. Bu açıdan tarafların birbirlerine zaman tanımaları önemlidir. Ayrıca Suriyelilerin Türkçe öğrenmesi ile Suriyelilere karşı yönelen önyargı büyük oranda azalmaktadır.

Araştırmada din dersi öğretmenlerinin yaşadıkları sorunlara karşı öne sürdükleri çözüm önerilerine de yer verilmiștir. Bu noktada öğretmenlerin

\footnotetext{
${ }^{39}$ Emin, Türkiye'deki Suriyeli Çocukların Eğitimi: Temel Eğitim Politikaları, s.22; Tanrıkulu, "Türkiye'de Yașayan Suriyeli Çocukların Eğitim Sorunu ve Çözüm Önerileri," ss.137-138.

${ }^{40}$ Bilgin, Türkiye'de Din Eğitimi ve Liselerde Din Dersleri, ss.23-33; Altaș, Gençlik Döneminde Din Olgusu ve Liselerde Din Öğretimi, ss.23-24; Recai Doğan ve Nurullah Altaș, "Din Öğretiminde Yeni Yöntem Tartışmalarında Kuramdan Uygulamaya: İlköğretim Din Kültürü ve Ahlak Bilgisi Programları (Ankara Modeli)," Değerler Eğitimi Dergisi 2:5 (2004), ss.23-38.

${ }^{41}$ Tüzün, Türkiye'de Mülteci Çocukların Eğitim Hakkını ve Karşılıklı Uyumu Destekleyen Yaklaşımlar, Politikalar ve Uygulamalar, s.53.

${ }^{42}$ Mithat Arman Karasu, "Türkiye'deki Suriyeli Sığınmacıların Kentlerde Neden Oldukları Güvenlik Riskleri," Sciences 36:2 (2018), ss.51-73; Hasan Çiftçi, “Türkiye Cumhuriyeti Vatandaşlarının Suriyeli Sığınmacılara Yönelik Tutum, Algı ve Empatik Eğilimlerinin Analizi," Insan ve Toplum Bilimleri Araștırmaları Dergisi 7:3 (2018), ss.2232-2256.
} 
dil eğitimi önerdikleri, dil eğitiminin sağlanması durumunda pek çok sorunun kendiliğinden çözümlendiğini bildirdikleri bilgisi önemlidir. Ayrıca önyarglların giderilmesi için karşılıklı empati eğitimleri de öğretmenlerin önerileri arasında yer almaktadır. Öğretmenler Suriyeli öğrenciler ile velilere yönelik uyum programlarının hayata geçirilmesini önermekte, uyum eğitiminin önemine özellikle vurgu yapmaktadırlar. Diğer öneriler, Suriyeli öğrencilere özel eğitim hizmeti sunan eğitim merkezlerinin kurulması, öğretmen ve öğrencilere Arapça öğretilmesi gibi pratik yaşantıdan uzak önerilerdir.

Suriyeli öğrenciler, Türkiye'deki pek çok ildeki imam hatip okullarında azınlık durumundadır ve bu öğrencilerin eğitim sistemine uyum sağlamaları farklı sosyal, ekonomik, kültürel ve bireysel unsurlardan etkilenmektedir. Suriyeli sığınmacı öğrencilerin öğrenim gördüğü sınıflarda derse giren din dersi öğretmenlerinin, bu öğrencilerin demografik farklılıkları ile yaşam şartları hakkında bilgi sahibi olması ve farklılıkları gözetecek şekilde öğrencilere yaklaşması önemlidir. Çok kültürlü veya farklı etnik kökenlere sahip öğrencileri aynı sınıfta bulundurmak farklı öğretimsel ve mesleki bilgileri zorunlu kllar. ${ }^{43} \mathrm{Bu}$ sebeple din dersi öğretmenlerine farklı dil, din ve ırka sahip öğrencilere nasıl yaklaşacağı, hangi öğretim yöntemlerini nasıl kullanacağı, sınıf içi iletişimi nasıl sağlayacağı gibi bilgilerin verilmesi gereklidir. Araştırma kapsamında din dersi öğretmenlerinin lisans eğitimleri sürecinde böylesi eğitimleri almadıkları belirlenmiştir. Söz konusu eksiklik hizmetiçi eğitimlerle kapatılabilir. İmam-hatip lisesine kayıt olan Suriyeli öğrenciler için Türkçe öğrenme şartı getirilebilir. Ayrıca Suriyelilerin yoğunlukta olduğu mahallelerde Türkçe dil ve okuma-yazma kursları açılmalıdır. Böylelikle sığınmacıların topluma uyumu kolaylaşacak ve çoğu sorunun altında yatan dil bilmeme sorunu çözüme kavuşturulacaktır. Suriyeli öğrencilerin din eğitimi konusundaki eksikliklerini gidermek amacıyla imam hatip lisesi bünyesinde hafta içi ders dışı veya hafta sonları telafi eğitimleri düzenlenebilir.

Bu araştırma Ankara ilindeki belirli imam hatip liselerinde çalışan sınırlı bir çalışma grubundan elde edilen verileri kapsamaktadır. Nitel desenler doğası gereği az sayıda örnekle çalışmayı gerektirdiğinden çalışma bulgularının genellemesinde sorunlar oluşabilir. İleride yapılacak çalışmaların nicel desenlerin genellemeye imkan tanıyan doğası ve nitel desenlerin ayrıntılara

\footnotetext{
${ }^{43}$ Alper Başbay ve Yelda Bektaș, “Çokkültürlülük Bağlamında Öğretim Ortamı ve Öğretmen Yeterlikleri," Eğitim ve Bilim 34:152 (2010), ss.34-35.
} 
odaklanma yeteneğini birleştiren karma desenlerle tasarlanması önerilebilir. Yalnızca Suriyeli öğrencileri konu edinen çalışmadan hareketle ileride yapılacak çalışmalar, farklı etnik kökenleri kapsayacak şekilde tüm yabancı uyruklu öğrenciler üzerinde de yürütülmelidir. Sosyal olguların dinamik ve değişken yapısı gereği, bu araştırmada toplanan veriler farklı dönemlerde farklı şehirlerden toplanan benzer örneklemlerle çelişkili sonuçlar verebilir. $\mathrm{Bu}$ açıdan araştırma sonuçları kendi bağlamı içinde değerlendirilmeli ve araştırma sorunsalının eş zamanlı farklılaşmaları kapsayacak bir olgu olduğu unutulmamalıdır.

\section{KAYNAKÇA}

Akpınar, Teoman. "Türkiye'deki Suriyeli Mülteci Çocukların ve Kadınların Sosyal Politika Bağlamında Yaşadıkları Sorunlar," Balkan and Near Eastern Journal of Social Sciences 3:3 (2017), ss.16-29.

Aksoy, Zeynep. "Uluslararası Göç ve Kültürler Arası İletişim,” Uluslararası Sosyal Araştırmalar Dergisi 5:20 (2012), ss.292-303.

Altaş, Nurullah. Gençlik Döneminde Din Olgusu ve Liselerde Din Öğretimi. Ankara: Nobel, 2004.

Aykırı, Kudret. "Sınıf Öğretmenlerinin Sınıflarındaki Suriyeli Öğrencilerin Eğitim Durumlarına İlişkin Görüşleri," Turkish Journal of Primary Education 2:1 (2017), ss.44-56.

Ayten, Ali ve Zeynep Sağır. "Dindarlık, Dinî Başa Çıkma ve Depresyon İlișkisi: Suriyeli Sığınmacılar Üzerine Bir Araştırma," Marmara Üniversitesi İlahiyat Fakültesi Dergisi 47:2 (2014), ss.5-18.

Baltacı, Ali. "Nitel Araştırmalarda Örnekleme Yöntemleri ve Örnek Hacmi Sorunsalı Üzerine Kavramsal Bir İnceleme," Bitlis Eren Üniversitesi Sosyal Bilimler Enstitüsü Dergisi 7:1 (2018), ss.231-274.

Baltacl, Ali ve Mehmet Kamil Coșkun. "Din Dersi Öğretmenlerine Yönelik Öğretmen Algısı Ölçeğinin Geliştirilmesi,” OPUS Uluslararası Toplum Araştırmaları Dergisi 8:15 (2018), ss.1450-1473.

Barın, Hilal. “Türkiye'deki Suriyeli Kadınların Toplumsal Bağlamda Yaşadıkları Sorunlar ve Çözüm Önerileri," Göç Araştırmaları Dergisi 2 (2015), ss.10-56.

Başbay, Alper ve Yelda Bektaş. "Çokkültürlülük Bağlamında Öğretim Ortamı ve Öğretmen Yeterlikleri," Eğitim ve Bilim 34:152 (2010), ss.30-43.

Batar, Yusuf. Empatik Din Eğitimi. Ankara: Elips Kitap, 2011.

Baxter, Pamela ve Susan Jack. "Qualitative Case Study Methodology: Study Design and Implementation for Novice Researchers," The Qualitative Report 13:4 (2008), ss.544-559.

Bengtsson, Mariette. "How to Plan and Perform a Qualitative Study Using Content Analysis," NursingPlus Open 2 (2016), ss.8-14.

Bilgin, Beyza. Türkiye'de Din Eğitimi ve Liselerde Din Dersleri. Ankara: Emel Matbaacllık, 1980. 
Bogdan, Robert ve Sari Knopp Biklen. Qualitative Research for Education. Boston: Allyn \& Bacon, 1997.

Boyraz, Zeki. “Türkiye'de Göçmen Sorununa Örnek Suriyeli Mülteciler," Zeitschrift für die Welt der Türken 7:2 (2015), ss.35-58.

Büyükikiz, Kadir Kaan ve Önder Çangal. "Suriyeli Misafir Öğrencilere Türkçe Öğretimi Projesi Üzerine Bir Değerlendirme," Uluslararası Türkçe Edebiyat Kültür Eğitim (TEKE) Dergisi 5:3 (2016), ss.1414-1430.

Canyurt, Dilek. "Suriye Gelișmeleri Sonrası Suriyeli Mülteciler: Türkiye'de Riskler," Akademik: Bakış Uluslararası Hakemli Sosyal Bilimler Dergisi 48 (2015), ss.127-146.

Cebeci, Suat. Din Eğitimi Bilimi ve Türkiye'de Din Eğitimi. Ankara: Akçağ, 1996.

Connelly, Lynne M. "Trustworthiness in Qualitative Research," Medsurg Nursing 25:6 (2016), ss.435-437.

Çelik, Yılmaz. “Arap Kökenli Öğrencilerin Yabancı Dil Olarak Türkçe Öğretiminde A Seviyesinde Yaptıkları Yazım Yanlışları ve Çözüm Önerileri," Anadolu Akademi Sosyal Bilimler Dergisi 1:1 (2007), ss.23-27.

Çiftçi, Hasan. "Türkiye Cumhuriyeti Vatandaşlarının Suriyeli Sığınmacılara Yönelik Tutum, Algı ve Empatik Eğilimlerinin Analizi," İnsan ve Toplum Bilimleri Araştırmaları Dergisi 7:3 (2018), ss.2232-2256.

Demir, Mehmet Akif. “İlköğretim Din Kültürü ve Ahlak Bilgisi Öğretmenliği Bölümü Öğrencilerinin Arapça Lisans Dersleri Hakkındaki Görüşleri: 19 Mayıs Üniversitesi İlahiyat Fakültesi Örneği," Cumhuriyet Üniversitesi İlahiyat Fakültesi Dergisi 18:1 (2014), ss.227-242.

Doğan, Recai ve Nurullah Altaş. "Din Öğretiminde Yeni Yöntem Tartışmalarında Kuramdan Uygulamaya: İlköğretim Din Kültürü ve Ahlak Bilgisi Programları (Ankara Modeli)," Değerler Eğitimi Dergisi 2:5 (2004), ss.23-38.

Duman, Betül. "Yoğun Göç Almış Metropollerde Etniklik ve Öteki İle İlişki," Sosyoloji Dergisi 3:27 (2013), ss.1-24.

Emin, Müberra Nur. Türkiye'deki Suriyeli Cocukların Eğitimi: Temel Eğitim Politikaları. Ankara: SETA, 2016.

Erdem, Cahit. "Sınıfında Mülteci Öğrenci Bulunan Sınıf Öğretmenlerinin Yaşadıkları Öğretimsel Sorunlar ve Çözüme Dair Önerileri,” Medeniyet Eğitim Araştırmaları Dergisi 1:1 (2017), ss.26-42.

Guiraudon, Virginie. "European Integration and Migration Policy: Vertical Policy-Making as Venue Shopping," JCMS: Journal of Common Market Studies 38:2 (2000), ss.251-271.

IOM. “IOM Turkey Report - Migrants' Presence Monitoring 2019”. IOM. 2019. https://turkey.iom.int/sites/default/files/Q1_quarterly-jan-feb-mar19.reduced.pdf. (Erişim: 16.04.2019).

Kap, Derya. "Suriyeli Mülteciler: Türkiye'nin Müstakbel Vatandaşları," Akademik Perspektif 1:3 (2014), ss.30-35.

Karasu, Mithat Arman. "Türkiye'deki Suriyeli Sı̆̆ınmacıların Kentlerde Neden Oldukları Güvenlik Riskleri," Sciences 36:2 (2018), ss.51-73.

Kartal, Bilhan. "Sığınmacı Statüsünün Dönüşümü ve Entegrasyon," Bilhan Kartal ve Ural Manço (ed.), Beklenmeyen Misafirler: Suriyeli Siğınmacılar Penceresin- 
den Türkiye Toplumunun Geleceği (Londra: Transnational Press, 2018) içinde, ss.117-139.

Kartal, Bilhan. "Türkiye’ye Yönelik Suriyeli Göçünün Çok Yönlü Doğasına Giriş”, Bilhan Kartal ve Ural Manço (ed.), Beklenmeyen Misafirler: Suriyeli Sığınmacılar Penceresinden Türkiye Toplumunun Geleceği (Londra: Transnational Press, 2018) içinde, ss.13-29.

Kaymakcan, Recep ve Hasan Meydan. "Din Kültürü ve Ahlak Bilgisi Programları ve Öğretmenlerine Göre Değerler Eğitimi," Değerler Eğitimi Dergisi 9:21 (2011), ss.29-55.

Kizilabdullah, Yildiz ve Tugrul Yuruk. "The Contribution of the Religious Culture and Ethics Course on the Integration of Children of Syrians in Adana, Turkey," Religious Education 113:3 (2018), ss.289-301.

Lee, Everett S. "A Theory of Migration," Demography 3:1 (1966), ss.47-57.

Miles, Matthew B. ve A. Michael Huberman. Qualitative Data Analysis: An Expanded Sourcebook. New York: Sage Publications Inc., 1994.

Morgan, Gareth ve Linda Smircich. "The Case for Qualitative Research," Academy of Management Review 5:4 (1980), ss.491-500.

Papastergiadis, Nikos. The Turbulence of Migration: Globalization, Deterritorialization and Hybridity. New York: John Wiley \& Sons, 2018.

Posel, Dorrit. "Have Migration Patterns in Post-Apartheid South Africa Changed?," Journal of Interdisciplinary Economics 15:3-4 (2004), ss.277-292.

Seydi, Ali Rıza. “Türkiye'nin Suriyeli Sığınmacıların Eğitim Sorununun Çözümüne Yönelik İzlediği Politikalar," Süleyman Demirel Üniversitesi Fen-Edebiyat Fakültesi Sosyal Bilimler Dergisi 31 (2014), ss.267-305.

Simini, Filippo, Marta C. González, Amos Maritan ve Albert-László Barabási. "A Universal Model for Mobility and Migration Patterns," Nature 484:7392 (2012), ss.96-100.

Şeker, Betül Dilara, İbrahim Sirkeci ve M. Murat Yüceşahin. Göç ve Uyum. Londra: Transnational Press, 2015.

Şimşek, Doğuş. “Göç Politikaları ve 'İnsan Güvenliği': Türkiye'deki Suriyeliler Örneği," Toplum ve Bilim 147 (2017), ss.11-26.

Tanrıkulu, Faik. “Türkiye'de Yaşayan Suriyeli Çocukların Eğitim Sorunu ve Çözüm Önerileri," Liberal Düşünce Dergisi 22:86 (2017), ss.127-144.

Tok, Mehmet ve Musa Yıgın. "Yabancı Uyruklu Öğrencilerin Türkçe Öğrenme Nedenlerine İlişkin Bir Durum Çalışması," Dil ve Edebiyat Eğitimi Dergisi 2/8 (2013), ss. 132-147.

Tosun, Aybiçe, Ayșe Yorulmaz, İshak Tekin ve Kübra Yıldız. "Mülteci Öğrencilerin Eğitim Sorunları, Eğitim ve Din Eğitiminden Beklentileri: Eskișehir Örneği," Eskişehir Osmangazi Üniversitesi Sosyal Bilimler Dergisi 19:1 (2018), ss.107-133.

Tüzün, Işık. Türkiye'de Mülteci Çocukların Eğitim Hakkını ve Karşılıklı Uyumu Destekleyen Yaklaşımlar, Politikalar ve Uygulamalar. Byy.: European Liberal Forum, 2017. 